\title{
Varietal diversity of Sri Lankan traditional rice based on sensitivity to temperature and photoperiod at vegetative stage
}

\author{
Elpitiya Udari Uvindhya Rathnathunga ${ }^{1}$, Gamini Senanayake ${ }^{2}$, Saman Seneweera ${ }^{3}$ and Sudarshanee \\ Geekiyanage $^{2 *}$ \\ ${ }^{I}$ Board of Study in Agriculture, Faculty of Graduate Studies, University of Ruhuna, Matara. \\ ${ }^{2}$ Department of Agricultural Biology, Faculty of Agriculture, University of Ruhuna, Mapalana, Kamburupitiya. \\ ${ }^{3}$ Centre for Crop Health, University of Southern Queensland, Toowoomba QLD 4350, Australia.
}

Submitted: 18 September 2017; Revised: 31 July 2017; Accepted: 28 September 2018

\begin{abstract}
Photoperiod and temperature are two important environmental factors affecting vegetative growth and yield of rice. The varietal diversity based on the response to temperature and photoperiod during vegetative growth was determined in a core collection of 40 Sri Lankan traditional rice accessions (SLTRA) and 2 improved and 2 wild rice types in terms of days to fully expansion of fifth leaf (DFL) and plant height (PH). Short day (SD), day neutral (DN) and long day (LD) conditions were imposed during 2 trials of high temperature (HT) and low temperature (LT) at $36.9 \pm 0.43{ }^{\circ} \mathrm{C}$ and $34.0 \pm 0.98{ }^{\circ} \mathrm{C}$ under natural temperature fluctuation. Average DFL of the collection at HT was significantly lower than that of the LT irrespective of photoperiods. Temperature affected the DFL of 22 accessions, while photoperiod alone affected 1 accession. Average PHs under HT were similar irrespective of the photoperiod, which were lower than those of LT. PH of 15 accessions was not affected by photoperiod or temperature. Temperature alone affected 12 accessions and photoperiod alone affected 2 accessions. Both photoperiod and temperature affected 4 accessions. In the cluster analysis on response to photoperiod and temperature, SLTRA and improved rice were differentiated into 2 clusters at a rescaled distance of 25 . Further, sub-clusters grouped several accessions of the same variety together. The differential varietal response to photoperiod and temperature in SLTRA would be useful in breeding for climate change adaptations after further experiments on flowering time and yield.
\end{abstract}

Keywords: Fifth leaf stage, Oryza sativa, photoperiod sensitivity, temperature, traditional rice.

\section{INTRODUCTION}

Extreme climatic events create adverse impacts on ecosystems affecting global crop production. Sri Lanka is an island, which has diverse climatic zones (National Atlas of Sri Lanka, 1988; Karl et al., 2008; Manawadu \& Fernando, 2008; De Costa, 2010; Irangani \& Shiratake, 2013). Photoperiod and temperature are two important environmental factors affecting rice flowering time and yield (Vergara \& Chang, 1985; Luan, 2009). Extreme temperatures adversely affect vegetative development and growth duration (Lansigan et al., 2000; Craufurd \& Wheeler, 2009; Wopereis et al., 2009; De Costa, 2010). Vegetative growth phase, reproductive phase and ripening phase are the three main phases of rice plant growth (Yoshida, 1981; Vergara \& Chang, 1985; Wopereis et al., 2009). There are two sub-phases of vegetative growth phase: photoperiod insensitive basic vegetative phase (BVP), and photoperiod sensitive phase (PSP). The rice plant must attain a certain amount of growth in the BVP based on its response to photoperiod before it reaches the PSP (Vergara \& Chang, 1985). Although there are several reports on estimates of the BVP and PSP, the transition from BVP to PSP is not well known (Chang et al., 1969; Vergara \& Chang, 1985; Nishida et al., 2001).

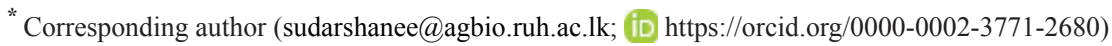


Temperature is an interrelated factor, which controls flowering time simultaneously with photoperiod (Vergara \& Chang, 1985). The increase in ambient temperature advances the flowering time in crops (Jagadish et al., 2016). Three categories of japonica varieties of Oryza sativa were recognised based on their temperature and photoperiod sensitivity in different regions in Japan: photoperiod sensitive but temperature insensitive varieties from Hokkaido and Tohoku; photoperiod insensitive but temperature sensitive varieties from south-west Japan; and varieties distributed in all parts of Japan except in Hokkaido, which are sensitive to both photoperiod and temperature (Wada, 1942; Chandraratne, 1964).

Yoshida (1981) explained that the number of leaves is an indication of the physiological stage of rice plant. The vegetative phase of rice is also affected by the interactions of photoperiod and temperature (Summerfield et al., 1992; Lansigan et al., 2000; Wopereis et al., 2009). There are studies on responses of wheat cultivars to differences in photoperiod and temperature and their interactions at early vegetative stage (Major, 1980; Slafer \& Rawson, 1994; Slafer \& Rawson, 1996). Tollenaar and Hunter (1983) reported the effect of photoperiod and temperature on the number of maize leaves at different stages of vegetative growth. Determination of photoperiod sensitivity through leaf senescence and tiller removal was conducted by Best (1961).

Sri Lankan rice germplasm consists of a large diversity of early flowering and late flowering varieties, which are photoperiod-sensitive or insensitive (Chandraratna, 1953; 1954; Yoshida, 1983; Rathnathunga et al., 2016a; Pushpakumari et al., 2017). Sri Lankan traditional rice Oryza sativa indica has been grown since ancient times, while Sri Lankan new improved rice has been bred through crosses between International Rice Research Institute (IRRI) accessions or crosses between Sri Lankan traditional rice. Wild rice species of Oryza rufipogon and Oryza nivara are the perennial and annual ancestors of $O$. sativa distributed in tropical and subtropical Asia (Khush, 1997; Shakiba \& Eizenga, 2014). Seasonal sensitivity in some Sri Lankan traditional rice accessions (SLTRA) is a major drawback in farmer introductions and inclusion in breeding programmes. Ma wee (accessions 4561, 6699 and 3683) and Maha ma wee (8696) did not flower in the latter part of north eastern monsoon (Maha) in 2012/2013 during the experimental period of 200 days (towards more day-neutral days with approximately 12 hours of day-length) in Sri Lanka (Rathnathunga et al., 2016a). During late Maha (LM) in 2013/2014 of more day-neutral days and early Maha (EM) of more short days with less than 12 hours of day-length in 2014/2015, 43 Ma wee accessions (close to the number of total $M a$ wee collection at the Plant Genetic Resources Centre, Sri Lanka) were grown under natural field conditions to determine the flowering time variation among accessions. All accessions flowered during EM and only nine accessions flowered out of 43 accessions during the experimental period of ten months in LM (Pushpakumari et al., 2017). There are no reports on the selection of rice accessions from Sri Lankan traditional rice germplasm for temperature sensitivity alone or for interaction of temperature and photoperiod for various agro-ecological systems as a remedy to future climatic fluctuations. Therefore, determination of varietal diversity in response to photoperiod and temperature at early vegetative growth could be useful in the selection of rice genotypes. In this study it was assumed that fifth leaf stage would be suitable to determine the vegetative growth responses as the first tiller emerges around the fifth leaf stage, usually making differences in the morphological structure of rice plant for flowering initiation (Yoshida, 1981; Moldenhauer \& Slaton, 2001).

The objective of this experiment was to determine the varietal diversity of SLTRA in response to temperature and photoperiod at early vegetative growth. The information will be useful to reveal genetic factors for future breeding programmes on ecological adaptation to overcome adverse effects of climate change.

\section{METHODOLOGY}

\section{Rice accessions}

Thirty six SLTRA were selected for the experiment from the Sri Lankan traditional rice core collection based on morphological characterisation (Rathnathunga et al., 2016a): Dahanala (DN) 2049, Duru wee (DW) 4626, Hondarawala (HO) 3521, 3528, 4070 and 6428, Kalu heenati (KH) 4089 and 5485, Kurulu wee (KL) 3601, Kiri murunga (KM) 3828, 3865 and 4102, Kaharamana (KR) 4260, Kalu wee (KW) 5492, Kottyaran (KY) 5513, Mada al (MA) 3854, Murungakayan (MK) 3495 and 5610, Mudukiriyal (MU) 3970 and 4144, Pachchaperumal (PP) 5546 and 5550, Sudu heenati (SH) 3355, Sulai (SU) 3968, 4365, 6287 and 6346, Sudu wee (SW) 3462, 3858, 4195 and 4594, Wanni heenati (WA) 3401, Ma wee (MW) 4561, 6699 and 3683, and Maha ma wee (MM) 8696. Two randomly selected Sri Lankan improved rice varieties for low country of Sri Lanka (At 308 and Ld 368) and 2 Sri Lankan wild rice species (O. nivara and $O$. rufipogon) collected from the low country of Sri Lanka were also included for the experimental collection. 


\section{Greenhouse experiment and management practices}

Rice accessions were grown under non-temperature controlled photoperiod chamber, with an average relative humidity of $80 \%$ at the University of Ruhuna, Kamburupitiya, Sri Lanka in the, low country Wet Zone (WL2). The experiment was carried out under three photoperiod conditions in a completely randomised design (CRD) with 3 replicates: $8 \mathrm{~h}$ of light and $16 \mathrm{~h}$ of darkness (short day; SD), $12 \mathrm{~h}$ of light and $12 \mathrm{~h}$ of darkness (day neutral; DN) and $14 \mathrm{~h}$ of light and $10 \mathrm{~h}$ of darkness (long day; LD), during late July to mid-October, 2014 and late November, 2014 to mid-February, 2015. The light intensity was set at $1600 \mu \mathrm{molm}^{-2} \mathrm{~s}^{-1}$. Average monthly temperature was recorded during the two experimental periods. The seeds were sown in separate cups and the seedlings were transplanted on pots of $20 \mathrm{~cm}$ diameter after $21 \mathrm{ds}$. Fertiliser application was conducted according to the recommendation of the Department of Agriculture, Sri Lanka during 2014-2015: The basal dressing [of urea, triple superphosphate (TSP) and muriate of potash (MOP) as 50, 62.5 and $50 \mathrm{~kg} / \mathrm{ha}$ ] and top dressings (of urea as 61.75, 123.5 and $123.5 \mathrm{~kg} / \mathrm{ha}$ ) were applied as adjusted to pot size at $2 \mathrm{wks}, 5 \mathrm{wks}$ and 7 wks of planting, respectively. Manual weeding was done at regular intervals and the competition from weeds was kept minimal. The temperature was recorded daily and the monthly average temperature was calculated.

\section{Measurements in fifth leaf stage of rice plant}

Measurements were based on descriptors of rice (Rathnathunga et al., 2014). Three quantitative morphological characters were recorded as follows; days to fully expansion of fifth leaf (DFL), plant height (PH) and culm number at DFL $(\mathrm{CN})$.

\section{Statistical analysis}

The average monthly temperature of trial 1 from July to October 2014 and trial 2 from November 2014 to February 2015 under greenhouse conditions were compared using t test. Boxplots and normal distribution curves were developed for DFL and $\mathrm{PH}$ for each treatment combination of $\mathrm{SD}, \mathrm{DN}$ and $\mathrm{LD}$ at low temperature (LT) and high temperature (HT) regimes using Minitab software (version 14), USA. Univariate analyses of variance (ANOVA) was conducted using SAS (9.1 version) statistical software and significant differences (at $\mathrm{p}<0.05)$ among treatments of photoperiod and temperature combinations were determined. Treatment means were separated using Duncan multiple range test (DMRT). Principal component analysis (PCA) and hierarchical cluster analysis by Ward's linkage (Onomo, et al., 2006; Giraldo, et al., 2010; Liu, et al., 2015) were performed using SPSS software (version 20), IBM, USA to determine the diversity among genotypes based on DFL and $\mathrm{PH}$ responses to treatment combinations of photoperiod and temperature.

\section{RESULTS AND DISCUSSION}

\section{Temperature difference between trials in greenhouse}

Average monthly temperatures of $36 \pm 0.38{ }^{\circ} \mathrm{C}$ in July, $38 \pm 0.45^{\circ} \mathrm{C}$ in August, $37 \pm 0.35^{\circ} \mathrm{C}$ in September

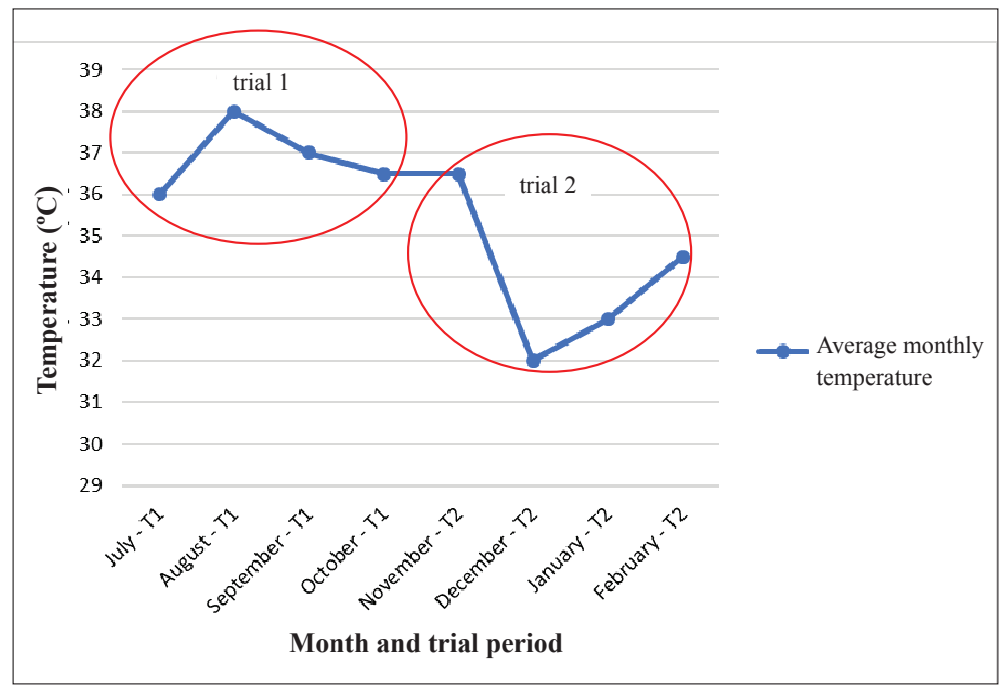

Figure 1: Natural temperature fluctuation during trial 1 (HT) and trial 2 (LT) 
and $36.5 \pm 0.54{ }^{\circ} \mathrm{C}$ in October, 2014 were recorded in trial 1 (Figure 1). The average monthly temperatures of trial 2 were $36.5 \pm 0.56{ }^{\circ} \mathrm{C}$ in November, $32 \pm 0.76^{\circ} \mathrm{C}$ in December, 2014, $33 \pm 0.97{ }^{\circ} \mathrm{C}$ in January and $34.5 \pm 0.67{ }^{\circ} \mathrm{C}$ in February, 2015 .

The average monthly temperature $\left(36.9 \pm 0.43^{\circ} \mathrm{C}\right)$ of trial 1 (HT) from July to October 2014 was significantly higher than that of trial $2\left(34.0 \pm 0.98{ }^{\circ} \mathrm{C}\right)$ (LT) from November 2014 to February 2015 under greenhouse conditions $\left(\mathrm{p}=0.036, \mathrm{r}^{2}=54.7 \%\right.$ and coefficient of variance $=4.26 \%$ ). Except temperature, other conditions such as water content, wind velocity etc. were kept constant among the 3 photoperiods in the 2 trials.

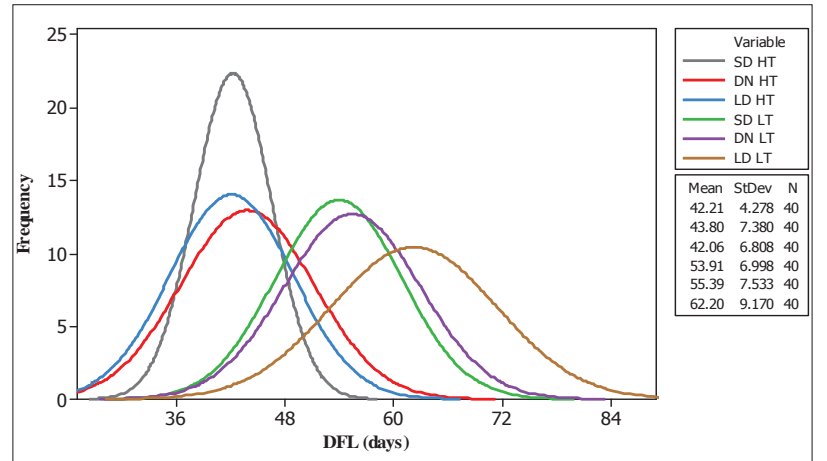

(a)

\section{Effect of photoperiod and trial temperature on DFL}

A wide variation in DFL in response to photoperiod and temperature of the trials could be identified among the 36 SLTRA, 2 wild rice and 2 improved rice varieties. The frequency distribution of DFL for the treatments (of SD under HT and LT, DN under HT and LT and, LD under HT and LT) were normally distributed (Figures 2a and 3a). Irrespective of the photoperiod, average DFL under LT was significantly higher than that under HT. Average DFL at LT were $54 \pm 1.10,55 \pm 1.19$ and $62 \pm$ 1.44 days under $\mathrm{SD}, \mathrm{DN}$ and $\mathrm{LD}$, respectively, where DFL under LD was significantly higher than those under SD and DN. DFL at HT were $42 \pm 0.68,44 \pm 1.17$ and

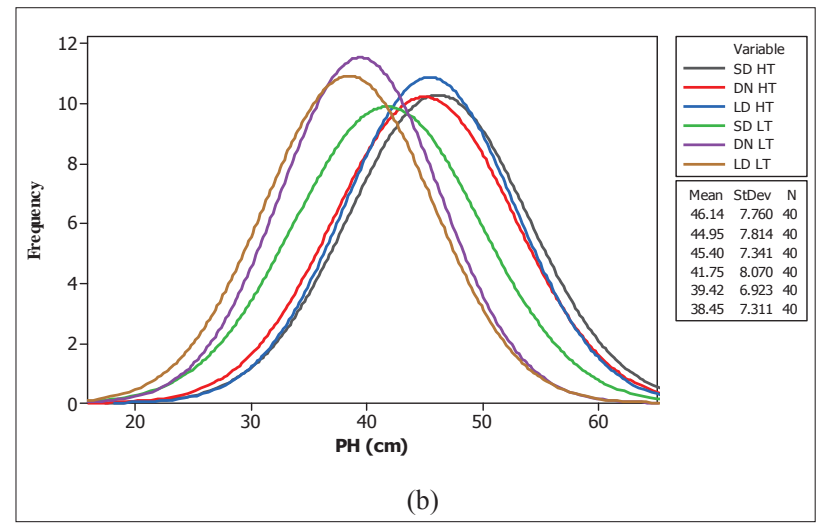

Figure 2: (a) Distribution of DFL of Sri Lankan traditional rice core collection under SD, DN and LD photoperiod conditions at LT and HT regimes; (b) distribution of $\mathrm{PH}$ of Sri Lankan traditional rice core collection under SD, DN and LD photoperiod conditions at LT and HT regimes.

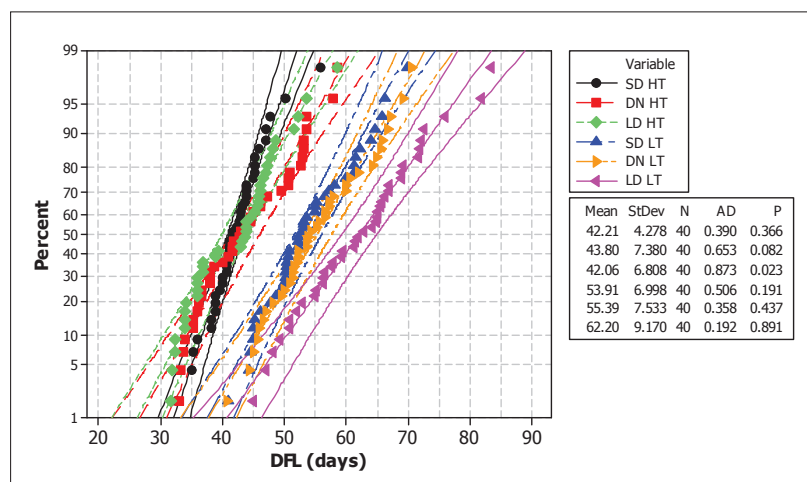

(a)

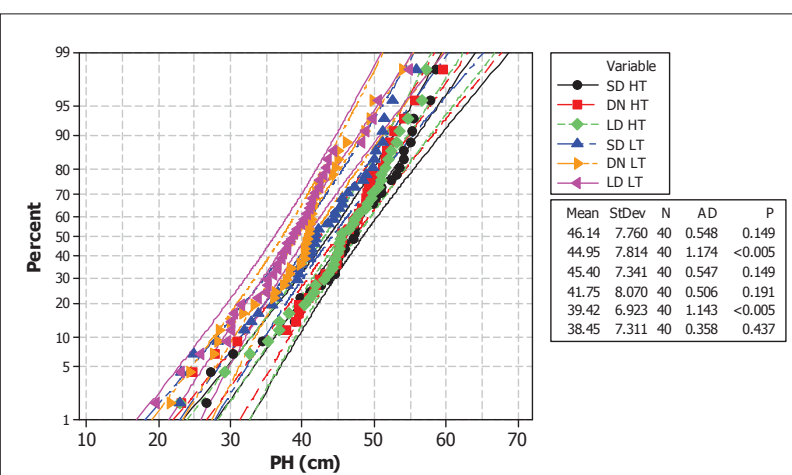

(b)

Figure 3: (a) Probability plot of DFL variation of Sri Lankan traditional rice core collection under SD, DN, LD photoperiod conditions at LT and HT regime; (b) probability plot of PH variation of Sri Lankan traditional rice core collection under SD, DN, LD photoperiod conditions at LT and HT regimes. 


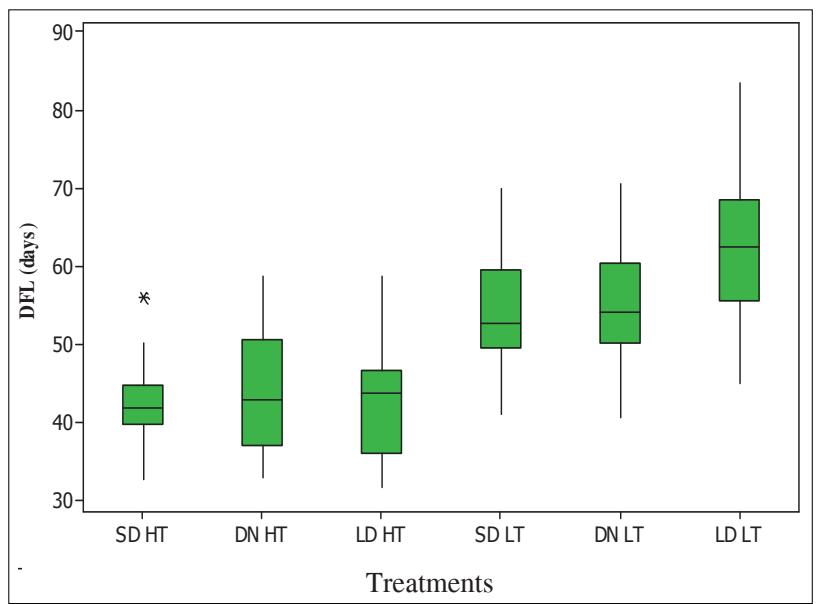

(a)

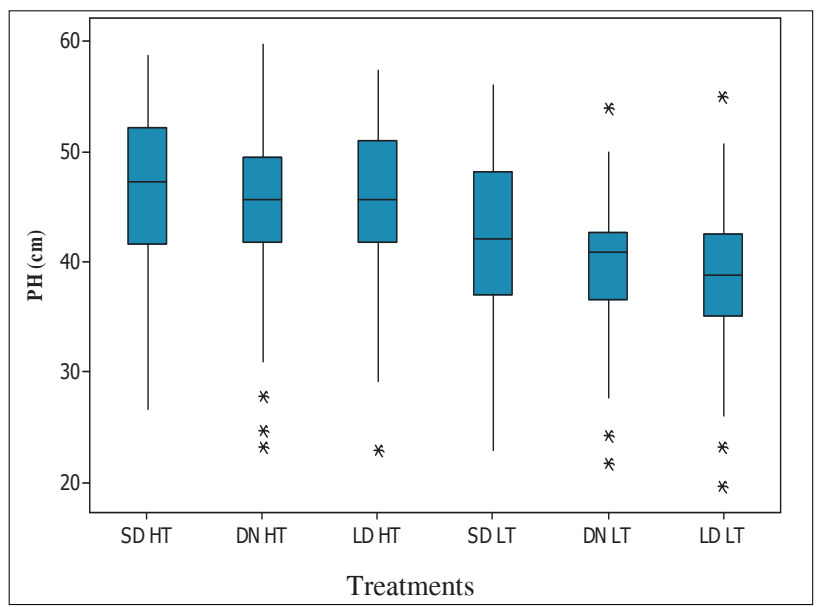

(b)

Figure 4: (a) Effect of photoperiod and temperature on distribution of DFL in Sri Lankan traditional rice core collection in boxplots; (b) effect of photoperiod and temperature on distribution of PH in Sri Lankan traditional rice core collection in boxplots Note: SDHT, DNHT and LDHT indicate SD, DN and LD photoperiods under HT, and SDLT, DNLT and LDLT indicate SD, DN and LD photoperiods under LT.

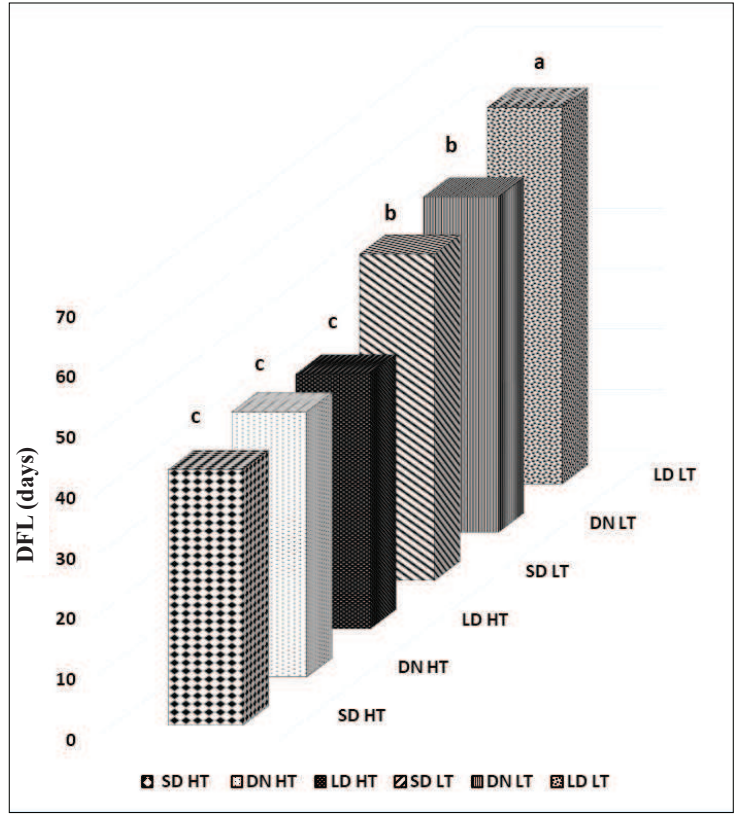

(a)

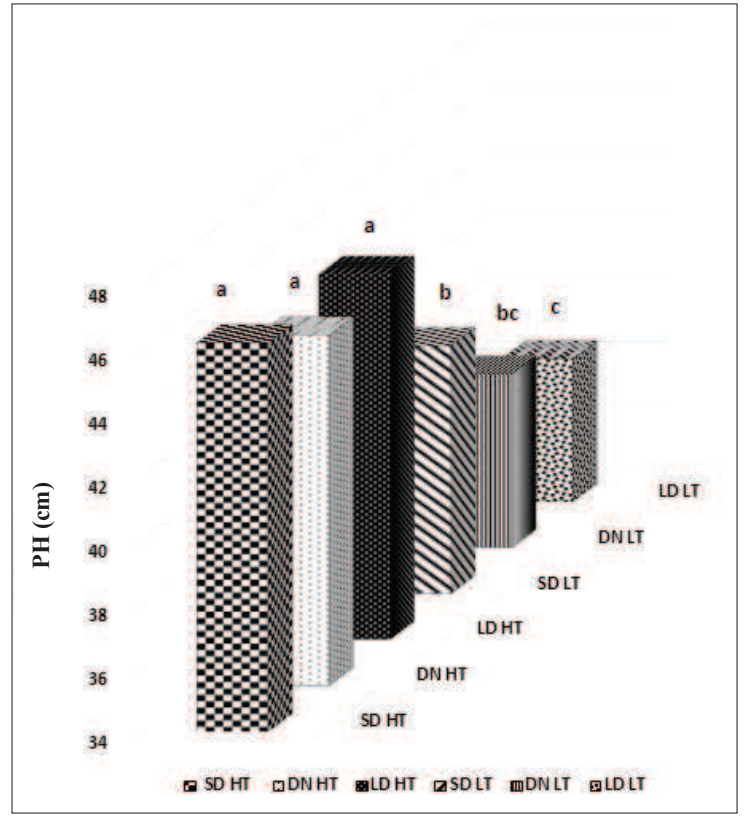

(b)

Figure 5: (a) Effect of photoperiod and temperature on DFL in Sri Lankan traditional rice core collection; (b) effect of photoperiod and temperature on PH in Sri Lankan traditional rice core collection

Note: SDHT, DNHT and LDHT indicate SD, DN and LD photoperiods under HT, and SDLT, DNLT and LDLT indicate $\mathrm{SD}, \mathrm{DN}$ and LD photoperiods under LT.

$42 \pm 1.08$ days under $\mathrm{SD}, \mathrm{DN}$ and $\mathrm{LD}$, respectively (Figures $4 \mathrm{a}$ and 5a). High temperatures increase the growth rate of rice with vigorous tillering (Yoshida, 1973). Ambient growth temperature determines the rates of metabolic interactions and morphogenetic processes in the plant (Long et al., 1988). Several key phytohormones are affected by temperature leading to morphological responses (Bita \& Gerats, 2013). 
Table 1: Response of Sri Lankan traditional rice to photoperiod, trial temperature and their interactions on DFL

\begin{tabular}{|c|c|c|c|c|c|c|}
\hline $\begin{array}{l}\text { Traditional rice } \\
\text { accession }\end{array}$ & R squared & $\mathrm{CV}$ value & $P$ value & Photoperiod & $\begin{array}{c}\text { Trial } \\
\text { temperature }\end{array}$ & $\begin{array}{c}\text { Photoperiod }{ }^{*} \text { trial } \\
\text { temperature }\end{array}$ \\
\hline Sulai 4365 & 61.60 & 12.63 & $0.0259^{*}$ & $0.011^{*}$ & 0.0637 & 0.4686 \\
\hline Hondarawala 4070 & 77.36 & 14.63 & $0.0014^{*}$ & 0.2146 & $0.0005^{*}$ & $0.0067^{*}$ \\
\hline Kiri murunga 3865 & 78.78 & 11.68 & $0.001^{*}$ & 0.0592 & $<0.0001^{*}$ & 0.5061 \\
\hline Mada al 3854 & 72.57 & 15.82 & $0.0353^{*}$ & 0.5765 & $0.0026^{*}$ & 0.5364 \\
\hline Sulai 6287 & 86.80 & 10.12 & $<0.0001^{*}$ & 0.4904 & $<0.0001^{*}$ & 0.2618 \\
\hline Pachchaperumal 5546 & 91.59 & 7.18 & $0.0012^{*}$ & 0.3607 & $0.0002^{*}$ & $0.0057^{*}$ \\
\hline Hondarawala 6428 & 92.08 & 6.63 & $<0.0001^{*}$ & $<0.0001^{*}$ & $<0.0001^{*}$ & 0.0558 \\
\hline Mudukiriyal 4144 & 93.83 & 7.16 & $<0.0001^{*}$ & $<0.0001^{*}$ & $<0.0001^{*}$ & 0.412 \\
\hline Kalu wee 5492 & 70.74 & 14.94 & $0.006^{*}$ & 0.4171 & $0.0006^{*}$ & 0.1022 \\
\hline Kiri murunga 3828 & 60.59 & 12.57 & $0.0297^{*}$ & 0.3895 & $0.0018^{*}$ & 0.7676 \\
\hline Hondarawala 3521 & 58.88 & 13.12 & $0.037^{*}$ & 0.0574 & $0.029^{*}$ & 0.1984 \\
\hline Sudu wee 4594 & 84.04 & 8.38 & $0.0002^{*}$ & $0.0014^{*}$ & 0.5136 & $0.0002^{*}$ \\
\hline Wanni heenati 3401 & 89.10 & 6.14 & $<0.0001^{*}$ & $0.0136^{*}$ & $<0.0001^{*}$ & 0.0547 \\
\hline Dahanala 2049 & 52.81 & 18.31 & 0.0747 & 0.3699 & $0.0099^{*}$ & 0.4143 \\
\hline Murungakayan 3495 & 91.14 & 7.87 & $<0.0001^{*}$ & $0.0183^{*}$ & $<0.0001^{*}$ & 0.1694 \\
\hline Pachchaperumal 5550 & 80.06 & 12.87 & $0.0014^{*}$ & 0.1884 & $0.0006^{*}$ & $0.0047^{*}$ \\
\hline Duru wee 4626 & 62.09 & 14.92 & $0.0245^{*}$ & 0.176 & $0.008^{*}$ & 0.1044 \\
\hline Kalu heenati 5485 & 76.07 & 14.44 & $0.002^{*}$ & 0.3908 & $0.0003^{*}$ & $0.0241^{*}$ \\
\hline Sudu heenati 3355 & 48.84 & 21.39 & 0.1112 & 0.6024 & $0.008^{*}$ & 0.8518 \\
\hline Kalu heenati 4089 & 75.41 & 10.46 & $0.0134^{*}$ & 0.8494 & $0.0007^{*}$ & 0.5031 \\
\hline Sudu wee 3462 & 90.65 & 8.65 & $0.0001^{*}$ & $0.0491^{*}$ & $<0.0001^{*}$ & $0.0006^{*}$ \\
\hline Kottyaran 5513 & 63.50 & 13.86 & $0.0198^{*}$ & $0.0471^{*}$ & $0.0078^{*}$ & 0.2901 \\
\hline Sulai 6346 & 87.50 & 15.14 & $0.0001^{*}$ & 0.113 & $<0.0001^{*}$ & $0.0006^{*}$ \\
\hline Sulai 3968 & 84.25 & 17.10 & $0.0002^{*}$ & $0.0335^{*}$ & $<0.0001^{*}$ & $0.0161^{*}$ \\
\hline Mudukiriyal 3970 & 89.25 & 10.71 & $<0.0001^{*}$ & 0.3439 & $<0.0001^{*}$ & 0.0877 \\
\hline Sudu wee 3858 & 49.11 & 11.05 & 0.1083 & 0.4078 & $0.0193^{*}$ & 0.3412 \\
\hline Kaharamana 4260 & 69.26 & 12.01 & $0.0078^{*}$ & 0.3088 & $0.0012^{*}$ & 0.0725 \\
\hline Sudu wee 4195 & 81.69 & 15.03 & $0.0004^{*}$ & $0.0224^{*}$ & $<0.0001^{*}$ & $0.0373^{*}$ \\
\hline Murungakayan 5610 & 71.43 & 12.62 & $0.0052^{*}$ & 0.1032 & $0.0004^{*}$ & 0.6392 \\
\hline Kiri murunga 4102 & 69.29 & 13.61 & $0.0078^{*}$ & 0.2444 & $0.0008^{*}$ & 0.1577 \\
\hline Hondarawala 3528 & 67.90 & 13.58 & $0.0099^{*}$ & 0.0508 & $0.0016^{*}$ & 0.5397 \\
\hline Kurulu wee 3601 & 82.95 & 11.11 & $0.0003^{*}$ & 0.9898 & $<0.0001^{*}$ & 0.9725 \\
\hline Ma wee 4561 & 73.50 & 11.73 & $0.0035^{*}$ & 0.0539 & $0.0005^{*}$ & 0.1862 \\
\hline Ma wee 6699 & 66.59 & 12.30 & $0.0193^{*}$ & 0.3124 & $0.0069^{*}$ & $0.0447^{*}$ \\
\hline Ma wee 3683 & 55.39 & 14.68 & 0.0563 & 0.1693 & $0.0118^{*}$ & 0.4013 \\
\hline Maha ma wee 8696 & 76.18 & 12.58 & $0.0065^{*}$ & 0.0672 & $0.001^{*}$ & 0.2132 \\
\hline At 308 & 72.99 & 12.38 & $0.0038^{*}$ & $0.0468^{*}$ & $0.0008^{*}$ & 0.1519 \\
\hline Ld 368 & 70.88 & 13.10 & $0.0058^{*}$ & 0.0866 & $0.0014^{*}$ & 0.0888 \\
\hline O. nivara & 67.21 & 8.95 & $0.0111^{*}$ & 0.9473 & $0.0004^{*}$ & 0.6203 \\
\hline O. rufipogon & 81.66 & 10.48 & $0.0009^{*}$ & 0.3748 & $<0.0001^{*}$ & $0.028^{*}$ \\
\hline
\end{tabular}

${ }^{*} \mathrm{p}<0.05$ significant level

Increasing temperature advances flowering time in crops (Jagadish et al., 2016). However, according to the results, HT above optimum in trial 2 retards the growth rate during early vegetative stage with extended DFL. It will be of importance to determine if temperature differently affects early vegetative growth stages of rice as indicated here. Fei et al. (2017) reported that higher ambient temperature can promote auxin biosynthesis in Arabidopsis by enhancing ethylene signalling for root morphological responses. Unravelling the temperature signal transduction pathway in rice leading to vegetative growth rate control would be an important target for climate change breeding as flowering time is correlated with vegetative growth. 
Effect of photoperiod, trial condition as temperature and their interaction on DFL was determined through ANOVA $F$ test for each accession. Twenty two accessions (accessions 3865, 3828 and 4102 of Kiri murunga, 6287 of Sulai, 3854 of Mada al, 5492 of Kalu wee, 3521 and 3528 of Hondarawala, 4626 of Duru wee, 2049 of
Dahanala, 3355 of Sudu heenati, 4089 of Kalu heenati, 3970 of Mudukirial, 3858 and 4195 of Sudu wee, 4260 of Kaharamana, 5610 of Murungakayan, 3601 of Kurulu wee, 4561, 6699 and 3683 of Ma wee, 8696 of Maha ma wee, Ld 368 and Oryza nivara) were affected by trial condition characterised by low temperature alone, which

Table 2: Effect of photoperiod, temperature, photoperiod and temperature interactions within each variety on DFL

\begin{tabular}{|c|c|c|c|c|c|c|c|}
\hline \multirow{2}{*}{\multicolumn{2}{|c|}{ Accession and variety }} & \multicolumn{3}{|c|}{ High temperature regime in trial 1} & \multicolumn{3}{|c|}{ Low temperature regime in trial 2} \\
\hline & & \multirow{2}{*}{$\begin{array}{l}\text { SD condition } \\
44 \mathrm{bc}\end{array}$} & \multirow{2}{*}{$\begin{array}{c}\text { DN condition } \\
36.3 \mathrm{c}\end{array}$} & \multirow{2}{*}{$\begin{array}{c}\text { LD condition } \\
48.3 \mathrm{ab}\end{array}$} & \multirow{2}{*}{$\begin{array}{c}\text { SD condition } \\
44.7 \mathrm{bc}\end{array}$} & \multirow{2}{*}{$\begin{array}{c}\text { DN condition } \\
44.3 \mathrm{bc}\end{array}$} & \multirow{2}{*}{$\begin{array}{c}\text { LD condition } \\
56.3 \mathrm{a}\end{array}$} \\
\hline 1 & Sulai 4365 & & & & & & \\
\hline 2 & Hondarawala 4070 & $35 \mathrm{~b}$ & $58.7 \mathrm{a}$ & $39 \mathrm{~b}$ & $62.3 \mathrm{a}$ & $55.3 \mathrm{a}$ & $66 \mathrm{a}$ \\
\hline 3 & Kiri murunga 3865 & $43.7 \mathrm{c}$ & $41 \mathrm{c}$ & $47 \mathrm{bc}$ & $57.3 \mathrm{~b}$ & $57.3 \mathrm{~b}$ & $69 \mathrm{a}$ \\
\hline 4 & Mada al 3854 & $35.3 \mathrm{c}$ & $40 \mathrm{bc}$ & $39.3 \mathrm{bc}$ & $50.5 \mathrm{abc}$ & $65 \mathrm{a}$ & $53 \mathrm{ab}$ \\
\hline 5 & Sulai 6287 & $47 \mathrm{~b}$ & $42.7 \mathrm{~b}$ & $46.7 \mathrm{~b}$ & $64 \mathrm{a}$ & $70.7 \mathrm{a}$ & $72.3 \mathrm{a}$ \\
\hline 6 & Pachchaperumal 5546 & $44 \mathrm{~b}$ & $46.3 \mathrm{~b}$ & $45.3 \mathrm{~b}$ & $70 \mathrm{a}$ & $50 \mathrm{~b}$ & $69 \mathrm{a}$ \\
\hline 7 & Hondarawala 6428 & $42.3 \mathrm{~d}$ & $43 \mathrm{~cd}$ & $53.7 \mathrm{~b}$ & $52.3 \mathrm{~b}$ & $49.5 \mathrm{bc}$ & $72 \mathrm{a}$ \\
\hline 8 & Mudukiriyal 4144 & $40.7 \mathrm{~d}$ & $36.7 \mathrm{~d}$ & $58.7 \mathrm{~b}$ & $50.3 \mathrm{c}$ & $52 \mathrm{c}$ & $72.7 \mathrm{a}$ \\
\hline 9 & Kalu wee 5492 & $47 \mathrm{c}$ & $41.7 \mathrm{c}$ & $46 \mathrm{c}$ & $53 \mathrm{bc}$ & $69.3 \mathrm{a}$ & $65 \mathrm{ab}$ \\
\hline 10 & Kiri murunga 3828 & $32.7 \mathrm{~b}$ & $38.7 \mathrm{ab}$ & $37 \mathrm{ab}$ & $44.3 \mathrm{a}$ & $46 \mathrm{a}$ & $47 \mathrm{a}$ \\
\hline 11 & Hondarawala 3521 & $46 \mathrm{~b}$ & $41.7 \mathrm{~b}$ & $48.7 \mathrm{~b}$ & $45.3 \mathrm{~b}$ & $52.3 \mathrm{ab}$ & $61.3 \mathrm{a}$ \\
\hline 12 & Sudu wee 4594 & $39 \mathrm{~b}$ & $53.7 \mathrm{a}$ & $43.3 \mathrm{~b}$ & $41 \mathrm{~b}$ & $40.7 \mathrm{~b}$ & $58 \mathrm{a}$ \\
\hline 13 & Wanni heenati 3401 & $41.3 \mathrm{~b}$ & $33.7 \mathrm{c}$ & $34 \mathrm{c}$ & $47.7 \mathrm{a}$ & $45 \mathrm{ab}$ & $48.3 \mathrm{a}$ \\
\hline 14 & Dahanala 2049 & $43.3 \mathrm{~b}$ & $45 \mathrm{~b}$ & $46.3 \mathrm{~b}$ & $53.3 \mathrm{ab}$ & $67.3 \mathrm{a}$ & $55 \mathrm{ab}$ \\
\hline 15 & Murungakayan 3495 & $39.7 \mathrm{c}$ & $46.3 \mathrm{c}$ & $46 \mathrm{c}$ & $61.3 \mathrm{~b}$ & $62 \mathrm{~b}$ & $71.7 \mathrm{a}$ \\
\hline 16 & Pachchaperumal 5550 & $40 \mathrm{bc}$ & $51 \mathrm{~b}$ & $34.3 \mathrm{c}$ & $48.7 \mathrm{~b}$ & $51.3 \mathrm{~b}$ & $65.3 \mathrm{a}$ \\
\hline 17 & Duru wee 4626 & $50.3 \mathrm{a}$ & $49.7 \mathrm{a}$ & $34 \mathrm{~b}$ & $53.7 \mathrm{a}$ & $57.3 \mathrm{a}$ & $56.7 \mathrm{a}$ \\
\hline 18 & Kalu heenati 5485 & $42.7 \mathrm{bc}$ & $44 \mathrm{bc}$ & $37 \mathrm{c}$ & $55 \mathrm{~b}$ & $51 \mathrm{~b}$ & $69.3 \mathrm{a}$ \\
\hline 19 & Sudu heenati 3355 & $42 \mathrm{~b}$ & $47.3 \mathrm{ab}$ & $43.7 \mathrm{~b}$ & $61.7 \mathrm{ab}$ & $65.7 \mathrm{a}$ & $56.3 \mathrm{ab}$ \\
\hline 20 & Kalu heenati 4089 & $41.3 \mathrm{bc}$ & $38 \mathrm{c}$ & $37 \mathrm{c}$ & $49.5 \mathrm{ab}$ & $51.5 \mathrm{a}$ & $52 \mathrm{a}$ \\
\hline 21 & Sudu wee 3462 & $43 \mathrm{~b}$ & $35.3 \mathrm{c}$ & $31.7 \mathrm{c}$ & $50 \mathrm{~b}$ & $47 \mathrm{~b}$ & $61.7 \mathrm{a}$ \\
\hline 22 & Kottyaran 5513 & $43 \mathrm{ab}$ & $50.7 \mathrm{a}$ & $34 \mathrm{~b}$ & $50.7 \mathrm{a}$ & $55.7 \mathrm{a}$ & $51 \mathrm{a}$ \\
\hline 23 & Sulai 6346 & $41.7 \mathrm{bc}$ & $36.7 \mathrm{c}$ & $32.3 \mathrm{c}$ & $45 \mathrm{bc}$ & $53.7 \mathrm{~b}$ & $83.5 \mathrm{a}$ \\
\hline 24 & Sulai 3968 & $39 c$ & $36 \mathrm{c}$ & $36 \mathrm{c}$ & $52.3 \mathrm{bc}$ & $56.7 \mathrm{~b}$ & $82 \mathrm{a}$ \\
\hline 25 & Mudukiriyal 3970 & $39 \mathrm{~b}$ & $33 \mathrm{~b}$ & $32.3 \mathrm{~b}$ & $55 \mathrm{a}$ & $53.7 \mathrm{a}$ & $62 \mathrm{a}$ \\
\hline 26 & Sudu wee 3858 & $40.7 \mathrm{ab}$ & $35.3 \mathrm{~b}$ & $43 \mathrm{ab}$ & $46.3 \mathrm{a}$ & $45.7 \mathrm{a}$ & $45 \mathrm{a}$ \\
\hline 27 & Kaharamana 4260 & $41.3 \mathrm{bc}$ & $34 \mathrm{c}$ & $47.3 \mathrm{ab}$ & $51 \mathrm{ab}$ & $54 \mathrm{a}$ & $51 \mathrm{ab}$ \\
\hline 28 & Sudu wee 4195 & $36 \mathrm{bc}$ & $33.3 \mathrm{c}$ & $36 \mathrm{bc}$ & $45 \mathrm{bc}$ & $48.3 \mathrm{~b}$ & $67 \mathrm{a}$ \\
\hline 29 & Murungakayan 5610 & $47.7 \mathrm{bcd}$ & $38 \mathrm{~d}$ & $45.7 \mathrm{dc}$ & $58.3 \mathrm{ab}$ & $54.3 \mathrm{abc}$ & $63 \mathrm{a}$ \\
\hline 30 & Kiri murunga 4102 & $45.3 \mathrm{c}$ & $42 \mathrm{c}$ & $44.7 \mathrm{c}$ & $50.3 \mathrm{bc}$ & $60 \mathrm{ab}$ & $65.3 \mathrm{a}$ \\
\hline 31 & Hondarawala 3528 & $45.3 \mathrm{bc}$ & $38 \mathrm{c}$ & $47.7 \mathrm{bc}$ & $53.3 \mathrm{ab}$ & $52.3 \mathrm{ab}$ & $64.3 \mathrm{a}$ \\
\hline 32 & Kurulu wee 3601 & $44 \mathrm{~b}$ & $44.7 \mathrm{~b}$ & $44 \mathrm{~b}$ & $66 \mathrm{a}$ & $66 \mathrm{a}$ & $67 \mathrm{a}$ \\
\hline 33 & Ma wee 4561 & $38.3 \mathrm{c}$ & $53.7 \mathrm{ab}$ & $51.7 \mathrm{~b}$ & $60 \mathrm{ab}$ & $60.7 \mathrm{ab}$ & $65.7 \mathrm{a}$ \\
\hline 34 & Ma wee 6699 & $38.3 \mathrm{c}$ & $53.3 \mathrm{ab}$ & $44 \mathrm{bc}$ & $55.3 \mathrm{ab}$ & $51.7 \mathrm{ab}$ & $59.5 \mathrm{a}$ \\
\hline 35 & Ma wee 3683 & $40 \mathrm{c}$ & $53 \mathrm{abc}$ & $44 \mathrm{bc}$ & $52.3 \mathrm{abc}$ & $56.7 \mathrm{ab}$ & $59.3 \mathrm{a}$ \\
\hline 36 & Maha ma wee 8696 & $40.7 \mathrm{bc}$ & $50.7 \mathrm{ab}$ & $36 \mathrm{c}$ & $50.5 \mathrm{ab}$ & $60 \mathrm{a}$ & $57.7 \mathrm{a}$ \\
\hline 37 & At 308 & $45 \mathrm{bc}$ & $53.3 \mathrm{ab}$ & $36 \mathrm{c}$ & $61.3 \mathrm{a}$ & $58 \mathrm{a}$ & $55.3 \mathrm{ab}$ \\
\hline 38 & $\operatorname{Ld} 368$ & $41.3 \mathrm{bc}$ & $44.7 \mathrm{~b}$ & $32 \mathrm{c}$ & $56.7 \mathrm{a}$ & $46.7 \mathrm{ab}$ & $49.3 \mathrm{ab}$ \\
\hline 39 & O. nivara & $56 \mathrm{bc}$ & $52.7 \mathrm{c}$ & $52.3 \mathrm{c}$ & $64.7 \mathrm{ab}$ & $66.7 \mathrm{a}$ & $66.3 \mathrm{a}$ \\
\hline 40 & O. rufipogon & $45.3 \mathrm{c}$ & $58 \mathrm{~b}$ & $46.3 \mathrm{c}$ & $66.3 \mathrm{ab}$ & $64.3 \mathrm{ab}$ & $76 \mathrm{a}$ \\
\hline
\end{tabular}

Different letters indicate the different significant levels among photperiod treatments under each temperature trial in each accession 


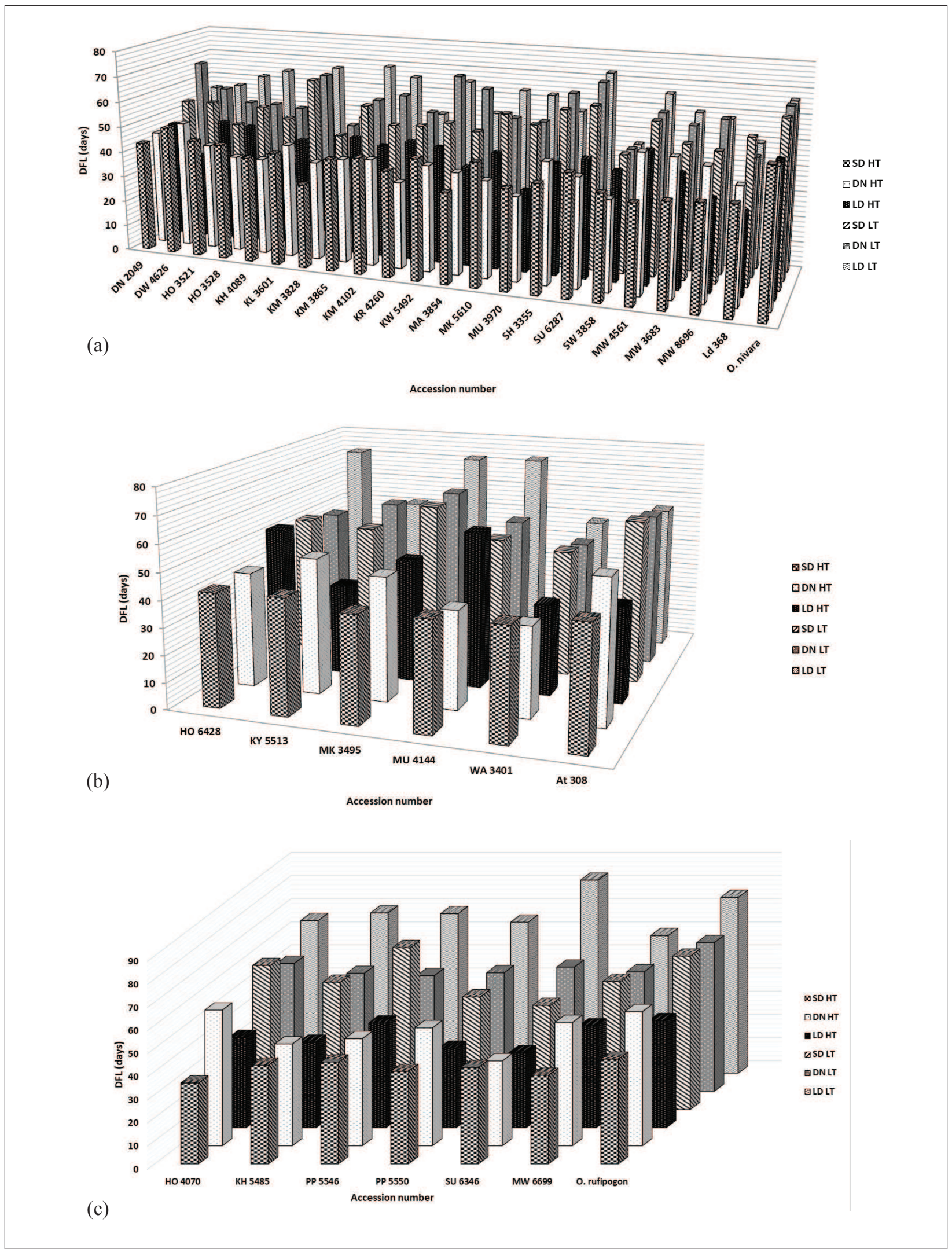

Continued - 
- continued from page 58

(d)
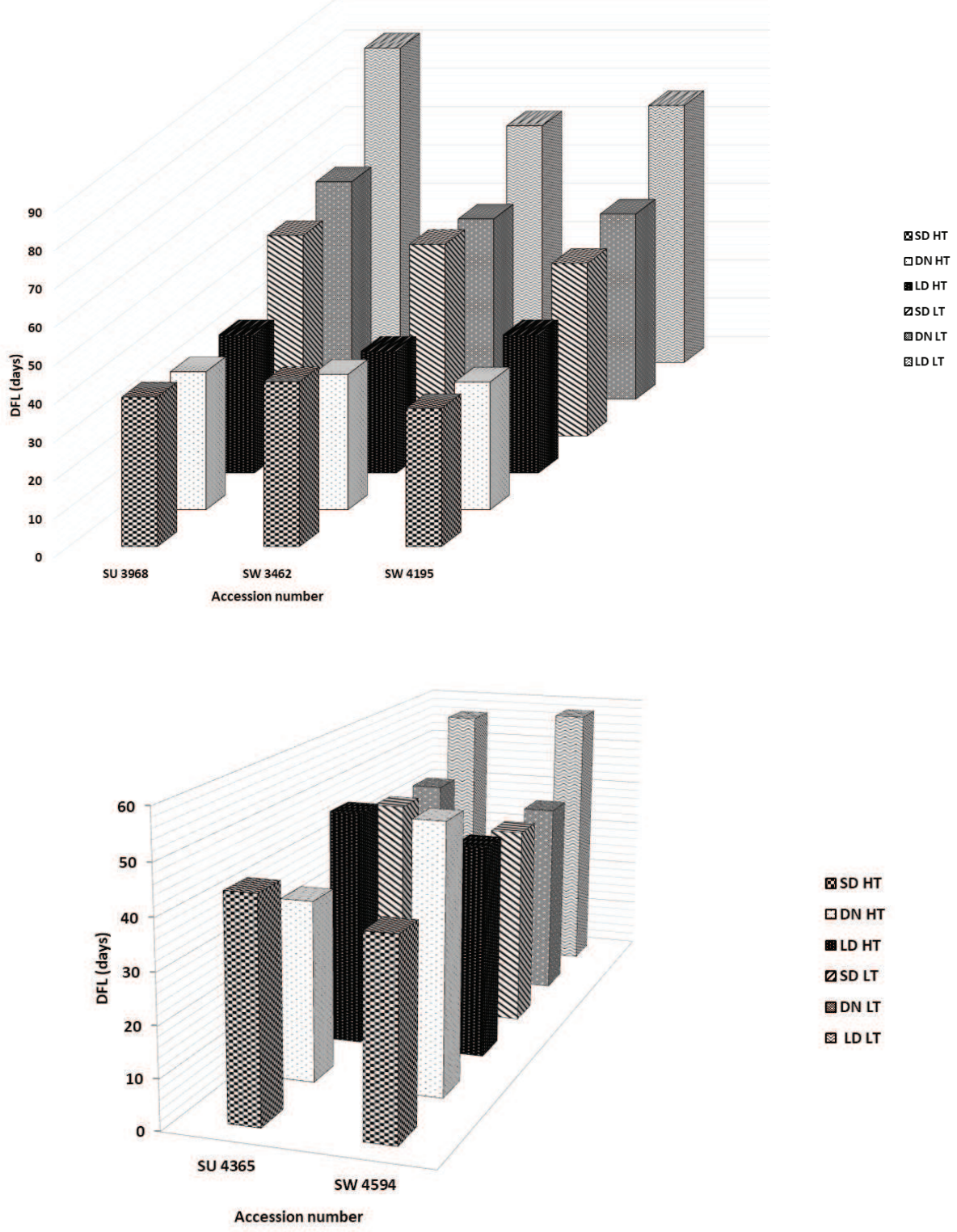

⿴囗十 SD HT

口DN HT

둘 LD HT

DSD LT

DDN LT

回 LD LT

(e)

Accession number

Figure 6: Effect of photoperiod and temperature on DFL of 40 Sri Lankan rice genotypes. Accessions affected by (a) temperature only; (b) photoperiod and temperature; (c) temperature and interaction between photoperiod and temperature; (d) photoperiod, temperature and interaction between photoperiod and temperature; (e) photoperiod only (Sulai 4365); photoperiod and interaction between photoperiod and temperature (Sudu wee 4594)

led to the extended DFL (Tables 1, 2 and Figure 6a). Photoperiod and trial temperature together affected accessions 6428 of Hondarawala, 4144 of Mudukirial, 3401 of Wanni heenati, 3495 of Murungakayan, 5513 of Kottyaran and At 308 (Figure 6b). Effect of temperature and interaction between photoperiod and temperature were identified in 7 accessions: 4070 of Hondarawala, 5546 and 5550 of Pachchaperumal, 5485 of Kalu heenati, 6346 of Sulai, 6699 of Ma wee and O. rufipogon (Figure 6c). Effect of photoperiod, trial temperature and their interaction were evident in accessions 3968 of variety Sulai, and 3462 and 4195 of variety Sudu wee (Figure 6d). 


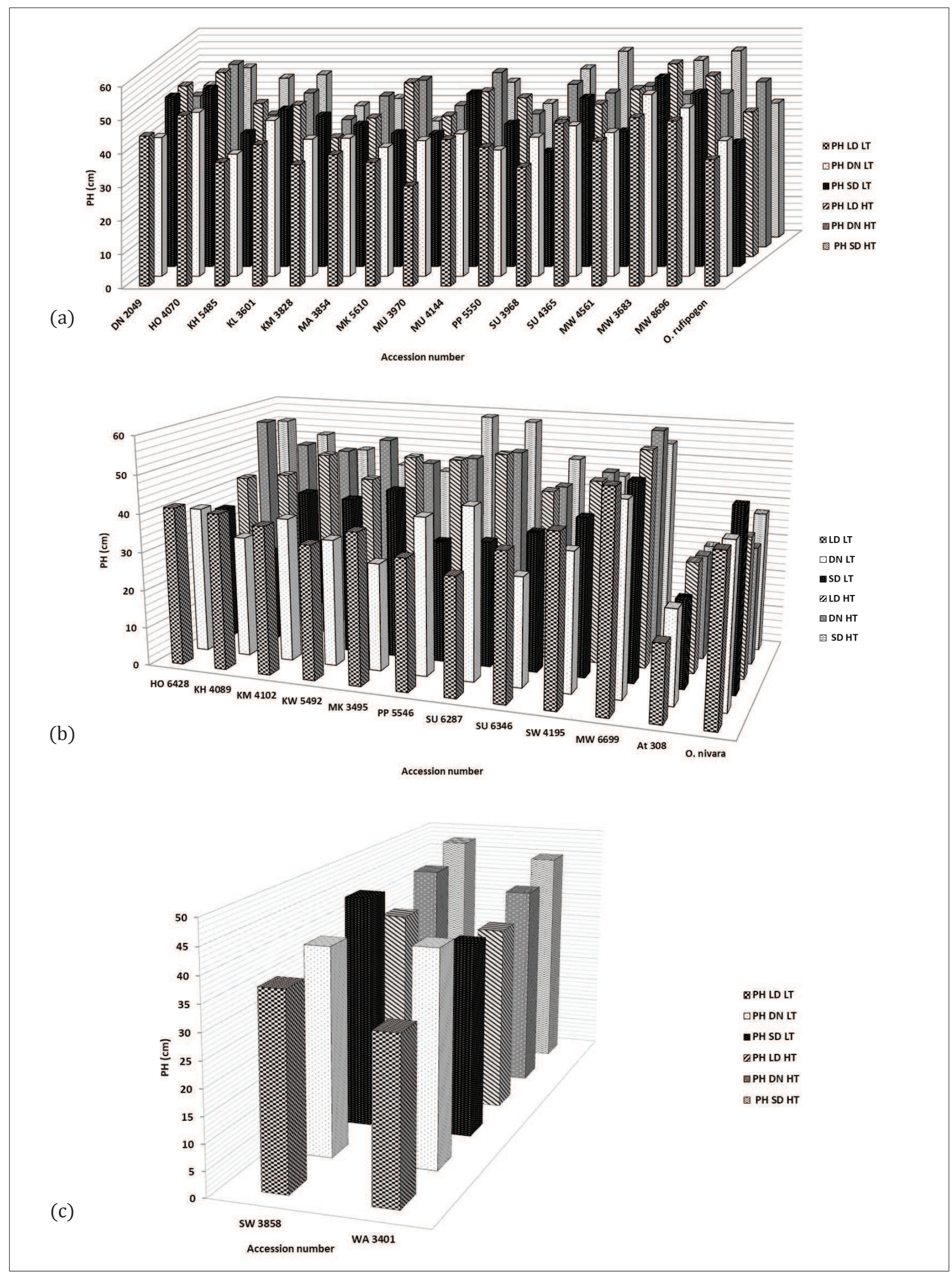

Continued - 
- continued from page 60

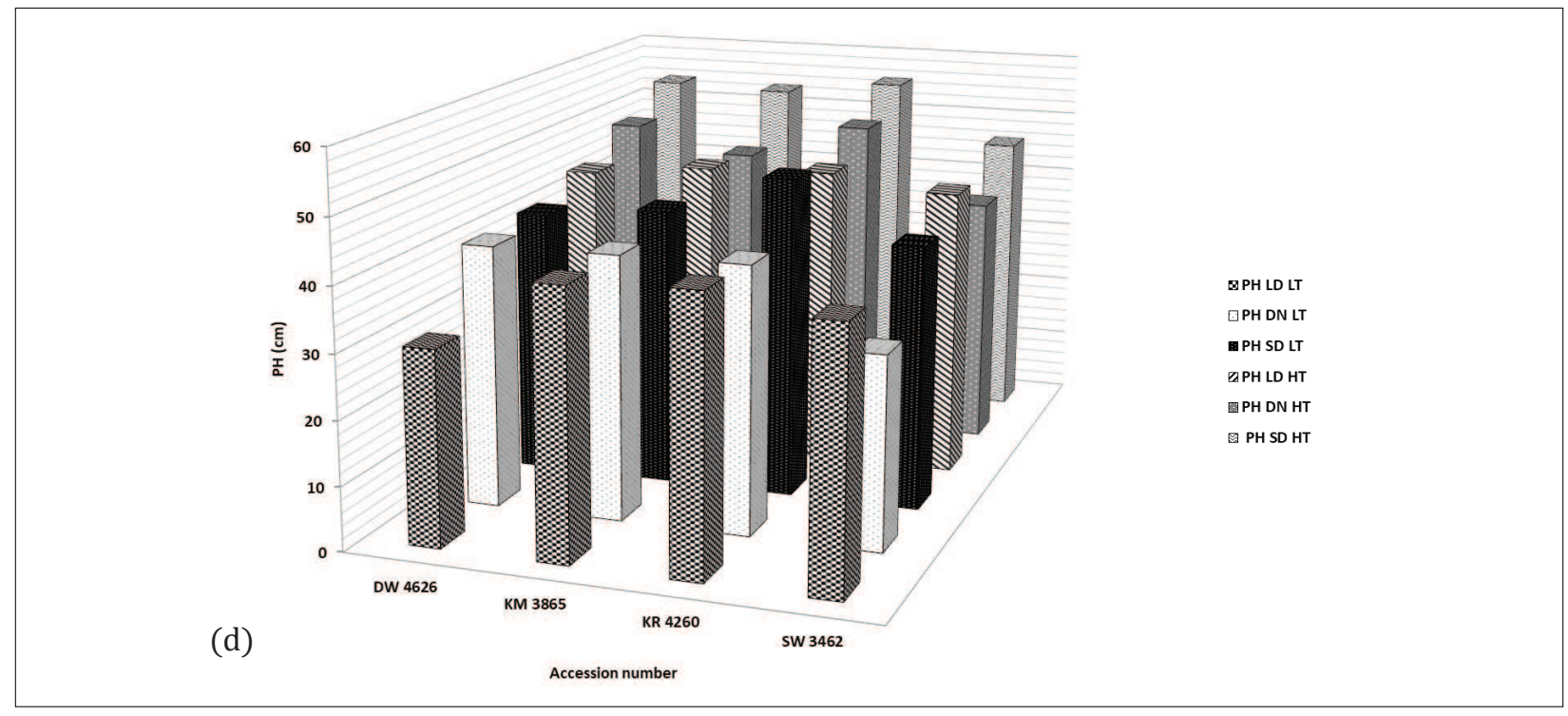

Figure 7: Effect of photoperiod and trial temperature on PH of 18 Sri Lankan traditional rice accessions from the collection. (a) Accessions did not respond to photoperiod, temperature or interaction; accessions responded to (b) temperature; (c) photoperiod; (d) photoperiod and temperature. $\mathrm{p}$ value $=0.001$ (significant level at $\mathrm{p}<0.05)$

The photoperiod effect only on DFL was evident in one accession (4365 of Sulai) with increased DFL under LD (Figure 6e). The photoperiod and interaction between trial temperature and photoperiod were evident only in accession 4594 of Sudu wee (Figure 6e).

Under both HT regime in trial 1 and LT regime in trial 2, 6287 of Sulai, 3970 of Mudukirial and 3601 of Kurulu wee had similar DFL for all 3 photoperiods (Tables 1 and 2). Flowering times of the above accessions in a later stage were of variable pattern under a relatively low average monthly temperature to that of trial 1 in the above 3 photoperiods (unpublished data): in 6287 of Sulai, DFL was significantly early under SD and significantly delayed under LD conditions; in 3970 of Mudukirial, DFL was significantly delayed under SD and DN conditions and the accession 3970 did not flower during the experimental period of 350 days under LD; the accession 3601 of Kurulu wee did not flower under DN or LD conditions during the experimental period. The above results suggest further experiments on temperature and photoperiod effect on DFL of these accessions as the prominent photoperiod effect could be masked by high temperature.

Accessions 5546 of Pachchaperumal, 5492 of Kalu wee, 3521 of Hondarawala, 2049 of Dahanala, 3968 and 6287 of Sulai and 4102 of Kiri murunga had similar DFL under HT for all 3 photoperiods, while 4070 of Hondarawala, 3828 of Kiri murunga, 4626 of Duru wee, 5513 of Kottyaran and 3858 of Sudu wee had similar DFL under LT irrespective of photoperiod. The above results indicate the potential of early flowering in non-photoperiod responsive rice accessions during rising temperature in the environment. It is important to evaluate the reduction of yield in such accessions when affected by HT for short life span. Among different SLTRA, the reduction of yield has been previously observed with increasing DFL under field conditions (Rathnathunga et al., 2016b, Rathnathunga \& Geekiyanage, 2016). However, in photoperiod sensitive accessions of SLTR Ma wee under field condition during early SD season only, variation in DFL and yield were positively correlated revealing that vegetative growth, DFL and yield were affected by seasonal sensitivity (Pushpakumari et al., 2017). Vergara and Chang (1985) indicated that almost all $O$. sativa indica rice accessions mature in a shorter time under a SD photoperiod than under a LD photoperiod, where the degree of sensitivity varies greatly among accessions. According to Collinson et al. (1992), photoperiod sensitive inductive phase was increased under LD.

It will be important to determine the effect of temperature on vegetative growth amid photoperiod effect. Photoperiod and temperature are important 
environmental factors affecting genetic factors of flowering time control in rice. The vegetative growth phase of rice comprises of photoperiod insensitive and photoperiod sensitive sub-phases, which are widely variable among accessions (Vergara \& Chang, 1985; Collinson et al., 1992; Luan et al., 2009; Hatfield
\& Prueger, 2015). According to Rathnathunga et al. (2016a), DFL of Sulai accessions 3968, 4365, 6287 and 6346 during the latter part of SD season (late Maha) towards more DN days in 2013 at the Rice Research and Development Institute, Batalagoda were 61, 68, 57 and 133 days, respectively. During this experiment, DFL of

Table 3: Response of Sri Lankan traditional rice to photoperiod, trial temperature and their interactions on PH

\begin{tabular}{|c|c|c|c|c|c|c|}
\hline $\begin{array}{l}\text { Traditional rice } \\
\text { accession }\end{array}$ & R squared & $\mathrm{CV}$ value & $P$ value & Photoperiod & $\begin{array}{c}\text { Trial } \\
\text { temperature }\end{array}$ & $\begin{array}{c}\text { Photoperiod * trial } \\
\text { temperature }\end{array}$ \\
\hline Sulai 4365 & 36.17 & 12.24 & 0.3057 & 0.1146 & 0.711 & 0.5074 \\
\hline Hondarawala 4070 & 20.73 & 9.94 & 0.6825 & 0.8965 & 0.3451 & 0.405 \\
\hline Kiri murunga 3865 & 68.81 & 7.31 & $0.0085^{*}$ & $0.0432^{*}$ & $0.0018^{*}$ & 0.3489 \\
\hline Mada al 3854 & 17.86 & 12.18 & 0.8701 & 0.5991 & 0.5903 & 0.8502 \\
\hline Sulai 6287 & 65.97 & 19.94 & $0.0136^{*}$ & 0.4972 & $0.0011^{*}$ & 0.202 \\
\hline Pachchaperumal 5546 & 78.20 & 12.56 & $0.0284^{*}$ & 0.3544 & $0.0037^{*}$ & 0.1806 \\
\hline Hondarawala 6428 & 63.22 & 16.89 & $0.0457^{*}$ & 0.37 & $0.0084^{*}$ & 0.1677 \\
\hline Mudukiriyal 4144 & 42.94 & 10.97 & 0.1891 & 0.7215 & 0.2126 & 0.0732 \\
\hline Kalu wee 5492 & 59.16 & 15.72 & $0.0357^{*}$ & 0.629 & $0.0057^{*}$ & 0.1186 \\
\hline Kiri murunga 3828 & 34.93 & 13.43 & 0.3311 & 0.1643 & 0.2385 & 0.7148 \\
\hline Hondarawala 3521 & 72.32 & 8.16 & $0.0044^{*}$ & $0.0089^{*}$ & $0.0206^{*}$ & $0.0273^{*}$ \\
\hline Sudu wee 4594 & 49.03 & 14.76 & 0.1092 & 0.1618 & 0.0688 & 0.2338 \\
\hline Wanni heenati 3401 & 52.89 & 12.68 & 0.074 & $0.0381^{*}$ & 0.1262 & 0.3822 \\
\hline Dahanala 2049 & 25.62 & 14.73 & 0.5541 & 0.4605 & 0.6849 & 0.3481 \\
\hline Murungakayan 3495 & 60.30 & 16.89 & $0.0308^{*}$ & 0.2064 & $0.0147^{*}$ & 0.0742 \\
\hline Pachchaperumal 5550 & 29.19 & 14.59 & 0.5106 & 0.3092 & 0.5608 & 0.4828 \\
\hline Duru wee 4626 & 88.12 & 7.56 & $<0.0001^{*}$ & $0.0005^{*}$ & $<0.0001^{*}$ & 0.2961 \\
\hline Kalu heenati 5485 & 34.99 & 17.07 & 0.3301 & 0.4034 & 0.0727 & 0.7362 \\
\hline Sudu heenati 3355 & 69.71 & 9.88 & $0.007^{*}$ & 0.5381 & $0.002^{*}$ & $0.0194^{*}$ \\
\hline Kalu heenati 4089 & 72.34 & 17.27 & $0.0217^{*}$ & 0.8831 & $0.0026^{*}$ & 0.0914 \\
\hline Sudu wee 3462 & 55.48 & 14.28 & 0.0557 & $0.0389^{*}$ & $0.034^{*}$ & 0.7394 \\
\hline Kottyaran 5513 & 48.81 & 18.44 & 0.1115 & 0.327 & 0.062 & 0.1354 \\
\hline Sulai 6346 & 47.33 & 21.81 & 0.1608 & 0.3916 & $0.0211 *$ & 0.7404 \\
\hline Sulai 3968 & 38.22 & 22.41 & 0.2656 & 0.4485 & 0.0549 & 0.5676 \\
\hline Mudukiriyal 3970 & 63.96 & 9.96 & $0.0185^{*}$ & 0.0838 & $0.0249 *$ & $0.0392^{*}$ \\
\hline Sudu wee 3858 & 48.70 & 11.37 & 0.1126 & $0.0255^{*}$ & 0.3351 & 0.8761 \\
\hline Kaharamana 4260 & 69.38 & 8.30 & $0.0077^{*}$ & $0.0109^{*}$ & $0.0042^{*}$ & 0.531 \\
\hline Sudu wee 4195 & 46.23 & 12.53 & 0.141 & 0.4744 & $0.0257^{*}$ & 0.3555 \\
\hline Murungakayan 5610 & 35.99 & 25.33 & 0.3093 & 0.4446 & 0.179 & 0.265 \\
\hline Kiri murunga 4102 & 54.87 & 12.26 & 0.0596 & 0.9183 & $0.0034^{*}$ & 0.5655 \\
\hline Hondarawala 3528 & 38.35 & 12.07 & 0.2631 & 0.9732 & 0.2515 & 0.089 \\
\hline Kurulu wee 3601 & 30.12 & 7.70 & 0.441 & 0.2006 & 0.4363 & 0.6676 \\
\hline Ma wee 4561 & 27.80 & 14.34 & 0.4985 & 0.6406 & 0.0805 & 0.9748 \\
\hline Ma wee 6699 & 43.84 & 8.91 & 0.2111 & 0.5534 & $0.0492^{*}$ & 0.3295 \\
\hline Ma wee 3683 & 33.18 & 13.20 & 0.3695 & 0.4816 & 0.6309 & 0.1676 \\
\hline Maha ma wee 8696 & 40.31 & 10.23 & 0.32 & 0.1864 & 0.5594 & 0.3418 \\
\hline AT308 & 69.29 & 10.51 & $0.0078^{*}$ & 0.5671 & $0.0006^{*}$ & 0.1474 \\
\hline LD368 & 61.73 & 10.06 & $0.0254^{*}$ & 0.0862 & 0.9002 & $0.0114^{*}$ \\
\hline O. nivara & 42.06 & 18.89 & 0.1996 & 0.4341 & $0.0257^{*}$ & 0.804 \\
\hline O. rufipogon & 37.37 & 16.08 & 0.3274 & 0.2829 & 0.1009 & 0.7762 \\
\hline
\end{tabular}

${ }^{*} \mathrm{p}<0.05$ significant level 
Table 4: Effect of photoperiod, temperature, photoperiod and temperature interactions within each variety on PH

\begin{tabular}{|c|c|c|c|c|c|c|c|}
\hline & & High ten & perature regime $\mathrm{i}$ & trial 1 & Low te & perature regime i & trial 2 \\
\hline Acces & on and variety & SD condition & DN condition & LD condition & SD condition & DN condition & LD condition \\
\hline 1 & Sulai 4365 & $55.2 \mathrm{a}$ & $45.7 \mathrm{a}$ & $45.3 \mathrm{a}$ & $50 \mathrm{a}$ & $44.7 \mathrm{a}$ & $48.3 \mathrm{a}$ \\
\hline 2 & Hondarawala 4070 & $50.3 \mathrm{a}$ & $54.2 \mathrm{a}$ & $54.7 \mathrm{a}$ & $52.7 \mathrm{a}$ & $48.7 \mathrm{a}$ & $50.7 \mathrm{a}$ \\
\hline 3 & Kiri murunga 3865 & $53.2 \mathrm{a}$ & $45.3 \mathrm{~b}$ & $46.7 \mathrm{~b}$ & $43.7 \mathrm{~b}$ & $41.3 \mathrm{~b}$ & $41.5 \mathrm{~b}$ \\
\hline 4 & Mada al 3854 & $41.2 \mathrm{a}$ & $44.8 \mathrm{a}$ & $41.2 \mathrm{a}$ & $42 \mathrm{a}$ & $41 \mathrm{a}$ & $39 \mathrm{a}$ \\
\hline 5 & Sulai 6287 & $58 \mathrm{a}$ & $51.7 \mathrm{a}$ & $53.3 \mathrm{a}$ & $33 \mathrm{~b}$ & $45 \mathrm{ab}$ & $30.7 \mathrm{~b}$ \\
\hline 6 & Pachchaperumal 5546 & $58.7 \mathrm{a}$ & $49.3 \mathrm{abc}$ & $51 \mathrm{ab}$ & $32 \mathrm{~d}$ & $41.3 \mathrm{bcd}$ & $34 \mathrm{~cd}$ \\
\hline 7 & Hondarawala 6428 & $54.3 \mathrm{ab}$ & $55.8 \mathrm{a}$ & $42 \mathrm{abc}$ & $35.8 \mathrm{c}$ & $38.5 \mathrm{bc}$ & $41.4 \mathrm{abc}$ \\
\hline 8 & Mudukiriyal 4144 & $46 \mathrm{a}$ & $51.8 \mathrm{a}$ & $49 \mathrm{a}$ & $51.3 \mathrm{a}$ & $42.3 \mathrm{a}$ & $43.5 \mathrm{a}$ \\
\hline 9 & Kalu wee 5492 & $43.7 \mathrm{ab}$ & $52.8 \mathrm{a}$ & $44.2 \mathrm{ab}$ & $41.2 \mathrm{ab}$ & $33.3 \mathrm{~b}$ & $35 \mathrm{~b}$ \\
\hline 10 & Kiri murunga 3828 & $39 \mathrm{a}$ & $37.8 \mathrm{a}$ & $35.3 \mathrm{a}$ & $44.7 \mathrm{a}$ & $40.7 \mathrm{a}$ & $36 \mathrm{a}$ \\
\hline 11 & Hondarawala 3521 & $51 \mathrm{a}$ & $41.7 \mathrm{bc}$ & $45.7 \mathrm{ab}$ & $45.3 \mathrm{ab}$ & $44.2 \mathrm{ab}$ & $35.3 \mathrm{c}$ \\
\hline 12 & Sudu wee 4594 & $30.5 \mathrm{a}$ & $24.7 \mathrm{ab}$ & $23 \mathrm{~b}$ & $23.2 \mathrm{~b}$ & $21.7 \mathrm{~b}$ & $23.2 \mathrm{~b}$ \\
\hline 13 & Wanni heenati 3401 & $45 \mathrm{a}$ & $41 \mathrm{a}$ & $36.8 \mathrm{ab}$ & $38 \mathrm{ab}$ & $41.8 \mathrm{a}$ & $31.5 \mathrm{~b}$ \\
\hline 14 & Dahanala 2049 & $45 \mathrm{a}$ & $44.8 \mathrm{a}$ & $50.7 \mathrm{a}$ & $50.3 \mathrm{a}$ & $41.2 \mathrm{a}$ & $44.5 \mathrm{a}$ \\
\hline 15 & Murungakayan 3495 & $42.7 \mathrm{a}$ & $47.2 \mathrm{a}$ & $51 \mathrm{a}$ & $44.5 \mathrm{a}$ & $28.3 \mathrm{~b}$ & $39.3 \mathrm{~b}$ \\
\hline 16 & Pachchaperumal 5550 & $39.7 \mathrm{a}$ & $39.5 \mathrm{a}$ & $47.2 \mathrm{a}$ & $42.3 \mathrm{a}$ & $37.5 \mathrm{a}$ & $41.2 \mathrm{a}$ \\
\hline 17 & Duru wee 4626 & $53.7 \mathrm{a}$ & $49.2 \mathrm{ab}$ & $44.7 \mathrm{bc}$ & $41.7 \mathrm{c}$ & $41 \mathrm{c}$ & $30.3 \mathrm{~d}$ \\
\hline 18 & Kalu heenati 5485 & $47.2 \mathrm{a}$ & $39.2 \mathrm{a}$ & $45.5 \mathrm{a}$ & $39.5 \mathrm{a}$ & $36.3 \mathrm{a}$ & 36.7 a \\
\hline 19 & Sudu heenati 3355 & $47.3 \mathrm{ab}$ & $52.3 \mathrm{a}$ & $52.5 \mathrm{a}$ & $49 \mathrm{a}$ & $39.7 \mathrm{bc}$ & $38 \mathrm{c}$ \\
\hline 20 & Kalu heenati 4089 & $51 \mathrm{a}$ & $50 \mathrm{a}$ & $43.7 \mathrm{ab}$ & $25 \mathrm{c}$ & $31.8 \mathrm{bc}$ & $40.8 \mathrm{ab}$ \\
\hline 21 & Sudu wee 3462 & $46 \mathrm{a}$ & $39.5 \mathrm{ab}$ & $45.3 \mathrm{a}$ & $41.3 \mathrm{a}$ & $30 \mathrm{~b}$ & $40 \mathrm{ab}$ \\
\hline 22 & Kottyaran 5513 & $47.3 \mathrm{a}$ & $42.5 \mathrm{ab}$ & $49.2 \mathrm{a}$ & $45.7 \mathrm{a}$ & $40.3 \mathrm{ab}$ & $30.2 \mathrm{~b}$ \\
\hline 23 & Sulai 6346 & $48.5 \mathrm{a}$ & $43.3 \mathrm{ab}$ & $44.5 \mathrm{ab}$ & $36.5 \mathrm{ab}$ & $28.5 \mathrm{~b}$ & $38 \mathrm{ab}$ \\
\hline 24 & Sulai 3968 & $50 \mathrm{a}$ & $48.3 \mathrm{a}$ & $40.3 \mathrm{a}$ & $34 \mathrm{a}$ & $41.3 \mathrm{a}$ & $35.3 \mathrm{a}$ \\
\hline 25 & Mudukiriyal 3970 & $39.5 \mathrm{a}$ & $42 \mathrm{a}$ & $41.8 \mathrm{a}$ & $39.3 \mathrm{a}$ & $40.3 \mathrm{a}$ & $29.7 \mathrm{a}$ \\
\hline 26 & Sudu wee 3858 & $47.7 \mathrm{a}$ & $44.3 \mathrm{ab}$ & $38.3 \mathrm{ab}$ & $45.7 \mathrm{ab}$ & $40.5 \mathrm{ab}$ & $37.3 \mathrm{~b}$ \\
\hline 27 & Kaharamana 4260 & $55.5 \mathrm{a}$ & $51.2 \mathrm{ab}$ & $47.3 \mathrm{bc}$ & $50.2 \mathrm{ab}$ & $41.5 \mathrm{c}$ & $42.5 \mathrm{c}$ \\
\hline 28 & Sudu wee 4195 & $44.7 \mathrm{ab}$ & $48 \mathrm{a}$ & $48 \mathrm{a}$ & $41.3 \mathrm{ab}$ & $36 \mathrm{~b}$ & $43.7 \mathrm{ab}$ \\
\hline 29 & Murungakayan 5610 & $34.5 \mathrm{a}$ & $49.5 \mathrm{a}$ & $51.7 \mathrm{a}$ & $39.5 \mathrm{a}$ & $38.3 \mathrm{a}$ & $36.7 \mathrm{a}$ \\
\hline 30 & Kiri murunga 4102 & $47.3 \mathrm{abc}$ & $49 a b$ & $50 \mathrm{a}$ & $42 a b c$ & $37.8 \mathrm{c}$ & $38.7 \mathrm{bc}$ \\
\hline 31 & Hondarawala 3528 & $44.7 \mathrm{ab}$ & $46.7 \mathrm{ab}$ & $52 \mathrm{a}$ & $48.5 \mathrm{ab}$ & $45 \mathrm{ab}$ & $40.3 \mathrm{~b}$ \\
\hline 32 & Kurulu wee 3601 & $48.2 \mathrm{a}$ & $45.7 \mathrm{a}$ & $45 \mathrm{a}$ & $46.5 \mathrm{a}$ & $46.3 \mathrm{a}$ & $42 \mathrm{a}$ \\
\hline 33 & Ma wee 4561 & $45.7 \mathrm{a}$ & $47.7 \mathrm{a}$ & $49.7 \mathrm{a}$ & $40 \mathrm{a}$ & $42.7 \mathrm{a}$ & $43 \mathrm{a}$ \\
\hline 34 & Ma wee 6699 & $54.3 \mathrm{ab}$ & $59.7 \mathrm{a}$ & $56.8 \mathrm{ab}$ & $51.3 \mathrm{ab}$ & $49.5 \mathrm{~b}$ & $55 \mathrm{ab}$ \\
\hline 35 & Ma wee 3683 & $52.5 \mathrm{a}$ & $45.3 \mathrm{a}$ & $57.3 \mathrm{a}$ & $56 \mathrm{a}$ & $54 \mathrm{a}$ & $50 \mathrm{a}$ \\
\hline 36 & Maha ma wee 8696 & $55.3 \mathrm{a}$ & $45.5 \mathrm{a}$ & $53.7 \mathrm{a}$ & $51.5 \mathrm{a}$ & $50 \mathrm{a}$ & $49 \mathrm{a}$ \\
\hline 37 & At 308 & $27.3 \mathrm{ab}$ & $27.8 \mathrm{ab}$ & $29.2 \mathrm{a}$ & $23 \mathrm{bc}$ & $24.3 \mathrm{abc}$ & $19.7 \mathrm{c}$ \\
\hline 38 & $\operatorname{Ld} 368$ & $26.7 \mathrm{~b}$ & $23.2 \mathrm{~b}$ & $32.7 \mathrm{a}$ & $28.3 \mathrm{ab}$ & $27.7 \mathrm{ab}$ & $26 \mathrm{c}$ \\
\hline 39 & O. nivara & $37.2 \mathrm{ab}$ & $31 \mathrm{~b}$ & $36.8 \mathrm{ab}$ & $47.3 \mathrm{a}$ & $42 \mathrm{ab}$ & $42.5 \mathrm{ab}$ \\
\hline 40 & O. rufipogon & $39.8 \mathrm{a}$ & $49 \mathrm{a}$ & $43 \mathrm{a}$ & $36.7 \mathrm{a}$ & $40.3 \mathrm{a}$ & $37.5 \mathrm{a}$ \\
\hline
\end{tabular}

Different letters indicate the different significant levels of photoperiod treatments under each temperature trial in each accession

the above accessions under SD in trial 1 at HT were 39, 44,47 and 41.7 days, while DFL under SD in trial 2 at LT were 52.3, 44.7, 64 and 45 days, respectively. The above results indicate the need for intensive studies on temperature and photoperiod interactions on vegetative growth and DFL of rice. Epistasis between flowering time genes $\mathrm{Sel}$ and Efl, which coordinate changes of photoperiod sensitivity, basic vegetative phase and optimum photoperiod was studied by Nishida et al. (2001) and Uwatoko et al. (2008). 
Effect of photoperiod and trial temperature on plant height at fifth leaf stage

The PH at DFL was considered as a vegetative growth parameter for biomass. A normal distribution in $\mathrm{PH}$ in response to photoperiod and temperature could be identified among 40 SLTRA, 2 wild and 2 improved rice varieties under SD, DN and LD, which varied from 32.7$56,33-58$ and $32-58.7 \mathrm{~cm}$ at HT and 41-70, 44.3-70.7 and $45-83.5 \mathrm{~cm}$ at LT, respectively (Figures $2 \mathrm{~b}$ and $3 \mathrm{~b}$ ). The variation of $\mathrm{PH}$ was plotted as 6 curves representing the treatments (SD under HT and LT, DN under HT and LT and LD under HT and LT). The PH values under all treatments were normally distributed (Figures 2b and $3 \mathrm{~b}$ ). Irrespective of the photoperiod, average $\mathrm{PH}$ values under HT were significantly higher (46 \pm 7.76 , $45 \pm 7.81$ and $45 \pm 7.31 \mathrm{~cm}$ under SD, DN and LD, respectively) than those under LT $(42 \pm 8.07,39 \pm 6.92$ and $38 \pm 7.31 \mathrm{~cm}$ under SD, DN and LD, respectively) (Figures $4 \mathrm{~b}$ and $5 \mathrm{~b}$ ). The above results suggest that the effect of high temperature on harvest index could be adverse as vegetative growth is increased under HT.

However, 15 accessions: 4365 of Sulai, 4070 of Hondarawala, 3854 of Mada al, 4144 of Mudukirial, 3828 of Kiri murunga, 2049 of Dahanala, 5550 of Pachchaperumal, 5485 of Kalu heenati, 3968 of Sulai, 5610 of Murungakayan, 3601 of Kurulu wee, 4561 and 3683 of Ma wee, 8696 of Maha ma wee and O. rufipogon were not responsive to photoperiod or temperature in terms of PH (Tables 3 and 4; Figure 7a).

Temperature alone affected the PH of 12 accessions: 6287 of Sulai, 5546 of Pachchaperumal, 6428 of Hondarawala, 5492 of Kalu wee, 3495 of Murungakayan, 4089 of Kalu heenati, 6346 of Sulai, 4195 of Sudu wee, 4102 of Kiri murunga, 6699 of Ma wee, At 308 and $O$. nivara. Among those, only in O. nivara, the $\mathrm{PH}$ increased under LT (Figure 7b). Photoperiod effect was only detected in 3401 of Wanni heenati and 3858 of Sudu wee (Figure 7c). Temperature and the interaction between photoperiod and temperature were evident in 3355 of Sudu heenati and 3970 of Mudukiriyal. Photoperiod effect and trial temperature effect were evident in 3865 of Kiri murunga, 4626 of Duru wee, 3462 of Sudu wee and 4260 of Kaharamana (Figure 7d). All 3 effects of photoperiod, trial temperature and interaction between photoperiod and temperature were detected from 3521 of Hondarawala (Table 4).

Rathnathunga and Geekiyanage (2017) reported the differential response of Ma wee accessions 6702, 6699 and 3683 to photoperiod on $\mathrm{PH}$ at early vegetative phase. Pushpakumari et al. (2017) reported that the above
3 accessions were sensitive to late SD season remaining in vegetative phase without flowering. In a photoperiod experiment by Padukkage et al. (2017), PH was increased in LD only or/and DN photoperiod in 28 early flowering accessions of SLTR during flowering time irrespective of the flowering response in LD and DN. According to Endo-Higashi and Izawa (2011), ambient environmental conditions may partially control sink size through the action of the flowering time genes.

\section{Regression analysis of days to fifth leaf and plant height}

There is a significant relationship between plant height and flowering time (Lin et al., 2012). As DFL is affected by photoperiod and temperature, $\mathrm{PH}$ may be controlled by pleiotrophic effects of flowering time genes at flowering. Delayed flowering increases PH (Rathnathunga et al., 2016a). The negative regression relationship between $\mathrm{PH}$ and DFL $(\mathrm{PH}=51.05-0.1675 \mathrm{DFL})(\mathrm{p}$ value $=0.001)$ in this study suggests that during early vegetative phase, $\mathrm{PH}$ may be independent of flowering time gene effect (Figure 8).

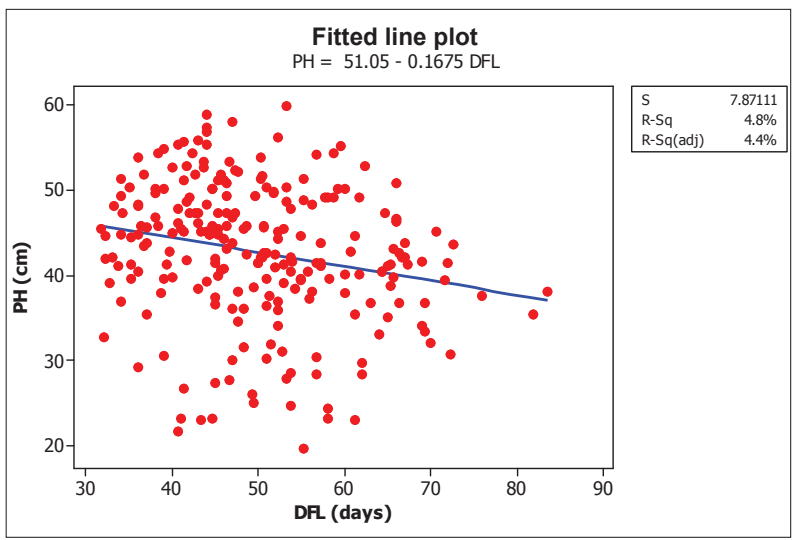

Figure 8: Regression analysis for relationship of DFL and PH of 40 Sri Lankan traditional rice accessions irrespective of temperature or photoperiod effect. $\mathrm{p}$ value $=0.001($ significant level at $\mathrm{p}<0.05)$

\section{Effect of photoperiod and trial temperature on culm number at fifth leaf stage}

The CN of the rice collection was neither affected by photoperiod nor temperature at fifth leaf stage. Padukkage et al. (2017) have previously reported that $\mathrm{CN}$ of very early flowering SLTRA was also not affected by the same photoperiod conditions. The effect of environmental factors on $\mathrm{CN}$ may vary on the environment, genotype 
and growth stage of rice. Pushpakumari et al. (2017) reported that the total $\mathrm{CN}$ of photoperiod sensitive $\mathrm{Ma}$ wee accessions at flowering was dependent on genotype and interaction between genotype and photoperiodic season under field conditions. Production of extremely high CN in SLTR variety Dewaraddili under LD condition was reported by Geekiyanage et al. (2012) under greenhouse condition.

Table 5: The major principal components through PCA of Sri Lankan rice collection based on response to photoperiod and temperature

\begin{tabular}{llll}
\hline PC & PC 1 & PC 2 & PC 3 \\
\hline Contribution to variation & $39.5 \%$ & $20.0 \%$ & $15.5 \%$ \\
Composition of characters & PH at HT under SD $(0.758)$ & DFL at HT under DN $(0.635)$ & DFL at HT under DN (0.531) \\
& PH at HT under DN $(0.818)$ & DFL at LT under SD $(0.837)$ & DFL at LT under LD (- 0.656) \\
& PH at HT under LD (0.897) & DFL at LT under DN (0.694) & \\
& PH at LT under SD $(0.757)$ & & \\
& PH at LT at DN (0.858) & & \\
& PH at LT under LD $(0.812)$ & & \\
\hline
\end{tabular}

\section{Varietal diversity in response to photoperiod and trial temperature}

Varietal diversity on differential response to photoperiod and temperature for vegetative growth though DFL and $\mathrm{PH}$ among tested SLTRA varieties could be detected. A principal component analysis (PCA) was performed for DFL, $\mathrm{PH}$ and $\mathrm{CN}$ of accessions under 3 photoperiods in each trial temperature. Seventy five percent of the total observed variation was explained by three principal components (PC), where $\mathrm{PH}$ under all treatments was included in PC1 (Table 5).

There were 2 main clusters at rescaled distance of 25 in the dendogram (Figure 9). Wild rice and all SLTRA excluding accession 4594 of Sudu wee were in the first cluster. Improved varieties (Ld 368 and At 308) and Sudu wee 4594 were included in the second cluster. In the first cluster, Sudu wee 3462 and 4195, Hondarawala 3521 and 3528, Kiri murunga 3865 and 4102, Sulai 6346 and 3968 Ma wee 3683 and 6699 and, O. nivara and O. rufipogan were grouped as pairs into sub-clusters at a rescaled distance less than 5. Accessions 3683, 6699 and 4561 of Ma wee, 4070 of Hondarawala, 2049 of Dahanala, 3601 of Kurulu wee and 8696 of Maha ma wee that did not flower or flowered very late during core collection development (Rathnathunga et al, 2016a) were included in one sub-cluster of the first cluster at a rescaled distance close to 10 .

The second major cluster comprised of the 2 improved varieties (Ld 368 and At 308) and Sudu wee 4594, which was morphologically close to improved rice in terms of plant architecture, yield components and DFL in all 3 photoperiods (Rathnathunga et al., 2016).
Identification of genetic factors associated with the diversity in temperature and photoperiod responses at early vegetative phase in terms of DFL and $\mathrm{PH}$ in the SLTRA would provide breeding materials for future work.

\section{CONCLUSION}

Naturally fluctuating LT $\left(34.0 \pm 0.43{ }^{\circ} \mathrm{C}\right)$ extended the average DFL of 40 Sri Lankan rice genotypes significantly over that under HT $\left(36.9 \pm 0.98{ }^{\circ} \mathrm{C}\right)$ irrespective of photoperiods. Among SLTRA the effect of temperature on DFL was more common (on 22 accessions out of 40) over that of photoperiod on DFL (one accession out of 40).

HT extended the average PH significantly in contrast to $\mathrm{LT}$ in the collection of 40 Sri Lankan rice genotypes. Fifteen accessions were not responsive to photoperiod or temperature on $\mathrm{PH}$ at DFL stage. Temperature alone affected 12 accessions and photoperiod alone affected 2 accessions. Increased DFL reduced the $\mathrm{PH}$ as indicated by regression relationship of $\mathrm{PH}=51.05-0.1675 \mathrm{DFL}$, suggesting the common phenomenon that extended vegetative period due to late flowering increases $\mathrm{PH}$, is not valid during early vegetative phase.

In hierarchical cluster analysis after PCA based on DFL and PH variation in response to temperature and photoperiod, SLTRA and wild rice were included into one cluster except for Sudu wee 4594 at rescale distance of 25 , which was close to improved rice in morphology, and was included into the second cluster with improved rice. 


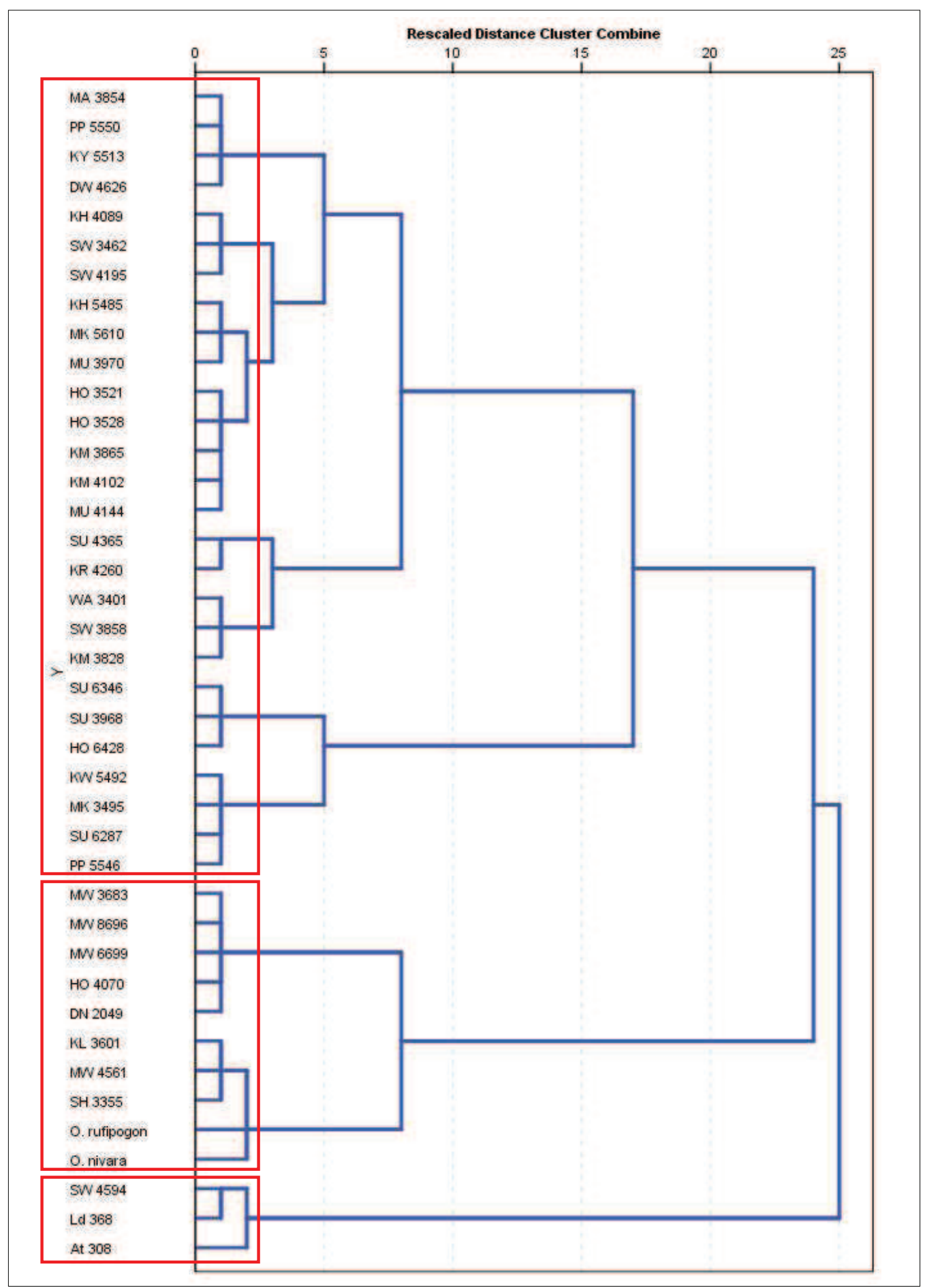

Figure 9: Diversity of experimental collection of 36 SLTRA, 2 improved rice and 2 wild rice on response to photoperiod and temperature based on the dendogram derived through cluster analysis

\section{Acknowledgement}

Authors acknowledge the National Research Council,
Sri Lanka for funding the research and the Plant Genetic Resources Centre, Gannoruwa, Sri Lanka for providing traditional rice seeds. 


\section{REFERENCES}

Best R. (1961). Some Aspects of Photoperiodism in Rice (Oryza sativa L.). Elsevier Publishing Company, Amsterdam, The Netherlands.

Bita C. \& Gerats T. (2013). Plant tolerance to high temperature in a changing environment: scientific fundamentals and production of heat stress-tolerant crops. Frontiers in Plant Science 4: 273.

DOI: https://doi.org/10.3389/fpls.2013.00273

Bonner J. (1940). Experiments on photoperiod in relation to the vegetative growth of plants. Plant Physiology 15(2): 319. DOI: https://doi.org/10.1104/pp.15.2.319

Chandraratna M.F. (1953). A gene for photoperiod sensitivity in rice linked with apiculus colour. Nature 171(4365): 1162-1163.

DOI: https://doi.org/10.1038/1711162a0

Chandraratna M.F. (1954). Photoperiod response in rice (Oryza sativa L.) I. Effects on inflorescence initiation and emergence. New Physiologist 53(3): 397-405. DOI: https://doi.org/10.1111/j.1469-8137.1954.tb05249.X

Chandraratna M.F. (1964). Genetics and Breeding of Rice. Longmans Publishing Company, Green and Co. Ltd., London, UK.

Chang T.T., Li C.C. \& Vergara B.S. (1969). Component analysis of duration from seeding to heading in rice by the basic vegetative phase and the photoperiod-sensitive phase. Euphytica 8(1): 79-91. DOI: https://doi.org/10.1007/BF00021985

Collinson S.T., Ellis R.H., Summerfield R.J. \& Roberts E.H. (1992). Durations of the photoperiod-sensitive and photoperiod-insensitive phases of development to flowering in four cultivars of rice (Oryza sativa L.). Annals of Botany 70(4): 339-346.

DOI: https://doi.org/10.1093/oxfordjournals.aob.a088483

Craufurd P.Q. \& Wheeler T.R. (2009). Climate change and the flowering time of annual crops. Journal of Experimental Botany 60(9): 2529-2539.

DOI: https://doi.org/10.1093/jxb/erp196

De Costa W.A.J.M. (2010). Adaptation of agricultural crop production to climate change: a policy framework for Sri Lanka. Journal of the National Science Foundation of Sri Lanka 38(2): 79-89.

DOI: http://doi.org/10.4038/jnsfsr.v38i2.2032

Endo-Higashi N. \& Izawa T. (2011). Flowering time genes heading date 1 and early heading date 1 together control panicle development in rice. Plant and cell physiology 52(6): 1083-1094.

Fei Q., Wei S., Zhou Z., Gao H. \& Li X. (2017). Adaptation of root growth to increased ambient temperature requires auxin and ethylene coordination in Arabidopsis. Plant Cell Reports 36(9): 1507-1518.

DOI: https://doi.org/10.1007/s00299-017-2171-7

Geekiyanage S., Madurangi S.A.P. \& Rathnathunga E.U.U. (2012). Effect of photoperiod on flowering time and attributed traits of selected Sri Lankan rice varieties, Proceedings of the $10^{\text {th }}$ Academic Sessions, University of Ruhuna, Sri Lanka, p. 70.
Giraldo E., López-Corrales M. \& Hormaza J.I. (2010). Selection of the most discriminating morphological qualitative variables for characterization of fig germplasm. Journal of the American Society for Horticultural Science 135(3): 240-249.

Hatfield J. \& Prueger J.H. (2015). Temperature extremes: effect on plant growth and development. Weather and Climate Extremes 10: 4-10.

DOI: https://doi.org/10.1016/j.wace.2015.08.001

Irangani M.K.L. \& Shiratake Y. (2013). Indigenous techniques used in rice cultivation in Sri Lanka: an analysis from an agricultural history perspective. Indian Journal of Traditional Knowledge 12(4): 638-650.

Jagadish S.K., Bahuguna R.N., Djanaguiraman M., Gamuyao R., Prasad P.V. \& Craufurd P.Q. (2016). Implications of high temperature and elevated $\mathrm{CO}_{2}$ on flowering time in plants. Frontiers in Plant Science 7: 913. DOI: https://doi.org/10.3389/fpls.2016.00913

Karl T.R., Meehl G.A., Peterson T.C., Kunkel K.E., Gutowskir W.J. \& Easterling D.R. (2008). Executive summary in weather and climate extremes in a changing climate. Regions of focus: North America, Hawaii, Caribbean, and US Pacific Islands. In: A Report by the US Climate Change Science Program and the Subcommittee on Global Change Research (eds. T.R. Karl, G.A. Meehl, C.D. Miller, S.J. Hassol, A.M. Waple \& W.L. Murray). Washington DC, USA.

Khush G.S. (1997). Origin, dispersal, cultivation and variation of rice. Plant Molecular Biology 35: 25-34.

DOI: https://doi.org/10.1023/A:1005810616885

Lansigan F.P., De Los Santos W.L. \& Coladilla J.O. (2000). Agronomic impacts of climate variability on rice production in the Philippines. Agriculture, Ecosystems and Environment 82(1): 129-137.

DOI: https://doi.org/10.1016/S0167-8809(00)00222-X

Lin Q. et al. (11 authors) (2012). Rice APC/C TE controls tillering by mediating the degradation of MONOCULM 1. Nature communications 3: 752.

Liu W., Shahid M.Q., Bai L., Lu Z., Chen Y., Jiang L., Diao M., Liu X. \& Lu Y. (2015). Evaluation of genetic diversity and development of a core collection of wild rice (Oryza rufipogon Griff.) populations in China. PLoS One 10(12): Article ID 0145990.

DOI: https://doi.org/10.1371/journal.pone.0145990

Long S.P. \& Woodward F.I. (1988). Plants and Temperature. Company of Biologists and Society for Experimental Biology (Great Britain). Cambridge, UK.

Luan W. et al. (11 authors) (2009). The effect of the crosstalk between photoperiod and temperature on the heading-date in rice. PLoS One 4(6): 5891.

DOI: https://doi.org/10.1371/journal.pone.0005891

Major D.J. (1980). Photoperiod response characteristics controlling flowering of nine crop species. Canadian Journal of Plant Science 60(3): 777-784. DOI: https://doi.org/10.4141/cjps80-115

Manawadu L. \& Fernando. N. (2008). Climate changes in Sri Lanka. University of Colombo Review. Journal of the University of Colombo, Sri Lanka. New Series 1: 02. 
Moldenhauer K. \& Slaton N. (2001). Rice growth and development, Rice Production Handbook, pp. 7-14. Available at http://www.uaex.edu/publications/pdf/mp192/ chapter-2.pdf.

National Atlas of Sri Lanka (1988). The National Atlas of Sri Lanka. Survey Department, Sri Lanka.

Nishida H., Okumoto Y., Nakagawa H., Ichitani K., Inoue H. \& Tanisaka T. (2001). Analysis of tester lines for rice (Oryza sativa L.) heading-time genes using reciprocal photoperiodic transfer treatments. Annals of Botany 88(4): 527-536.

DOI: https://doi.org/10.1006/anbo.2001.1490

Onomo P.E., Niemenak N. \& Ndoumou D.O. (2006). Morphological variability of Cola acuminata [(Pal. De Beauv.) Schott et Endl.] germplasm in Cameroon. Pakistan Journal of Biological Sciences. 9: 398-403. DOI: https://doi.org/10.3923/pjbs.2006.398.403

Padukkage D., Senanayake G. \& Geekiyanage S. (2017). Photoperiod sensitivity of very early maturing Sri Lankan rice for flowering time and plant architecture. Open Agriculture 2 (1): 580-588.

DOI: https://doi.org/10.1515/opag-2017-0061

Pushpakumari W.H.D.U., Senanayake G. \& Geekiyanage S. (2017). Photoperiod driven days to flowering variation affects vegetative growth and yield in Sri Lankan traditional rice (Oryza sativa L.) Ma Wee. Pakistan Journal of Botany 49 (3): 945-954.

Rathnathunga E.U.U., Pushpakumari W.H.D.U., Padukkage P.D.C., Dissanayake N., Fernando K., Rathnasiri P.W., Senanayake S.G.J.N., Senaweera S. \& Geekiyanage S. (2014). Handbook on Varietal Diversity of Sri Lankan Traditional Rice (Oryza sativa L.), volume I. University of Ruhuna, Sri Lanka.

Rathnathunga E.U.U. \& Geekiyanage S. (2015). Potential flowering time mutants of Sri Lankan traditional rice variety "Sulai", Proceedings of National Symposium on Agriculture, Faculty of Agriculture, Eastern University, Sri Lanka.

Rathnathunga E.U.U., Senanayake S.G.J.N., Dissanayake N., Seneweera S. \& Geekiyanage S. (2016a). Development of a mini core collection from Sri Lankan traditional rice for flowering time variation. Australian Journal of Crop Science 10(9): 1357-1367.

DOI: https://doi.org/10.21475/ajcs.2016.10.09.p7865

Rathnathunga E.U.U., Senanayake S.G.J.N., Dissanayake N., Seneweera S. \& Geekiyanage S. (2016b). Vegetative growth and yield associated flowering time variation in Sri Lankan rice "Hondarawala". The Journal of Agricultural Sciences 11(1): 42-52.

DOI: http://doi.org/10.4038/jas.v11i1.8079

Rathnathunga E.U.U. \& Geekiyanage S. (2016). Within variety flowering time variation leads to yield variation in Sri Lankan traditional rice "Sudu wee". Ceylon Journal of Science 45(2): 25-37.

DOI: http://doi.org/10.4038/cjs.v45i2.7386

Rathnathunga E.U.U. \& Geekiyanage S. (2017). Responses of Sri Lankan traditional rice to photoperiod at early vegetative stage. Pakistan Journal of Botany 49(1): 63-66.

Shakiba E. \& Eizenga G.C. (2014). Unravelling the secrets of rice wild species. Rice: Germplasm, Genetics, and
Improvement. In TechOpen Limited, London, UK. DOI: http://doi.org/10.5772/58393

Slafer G.A. \& Rawson H.M. (1994). Sensitivity of wheat phasic development to major environmental factors: a reexamination of some assumptions made by physiologists and modellers. Functional Plant Biology 21(4): 393-426. DOI: https://doi.org/10.1071/PP9940393

Slafer G.A. \& Rawson H.M. (1996). Responses to photoperiod change with phenophase and temperature during wheat development. Field Crops Research 46(1): 1-13. DOI: https://doi.org/10.1016/0378-4290(95)00081-X

Song M.T., Lee J.H., Cho Y.S. \& Hwang H.G. (2002). Effect of temperature associated with early growth stimulus on shortening of heading dates in rice. Plant Resources 5(2): $155-160$.

Summerfield R.J., Collinson S.T., Ellis R.H., Roberts E.H. \& De Vries F.P. (1992). Photothermal responses of flowering in rice (Oryza sativa). Annals of Botany 69(2): 101-112. DOI: https://doi.org/10.1093/oxfordjournals.aob.a088314

Tollenaar M. \& Hunter R.B. (1983). A photoperiod and temperature sensitive period for leaf number of maize. Crop Science 23(3): 457-460.

DOI: https://doi.org/10.2135/cropsci1983.0011183X0023 $00030004 x$

Uwatoko N., Onishi A., Ikeda Y., Kontani M., Sasaki A., Matsubara K., Itoh Y. \& Sano Y. (2008). Epistasis among the three major flowering time genes in rice: coordinate changes of photoperiod sensitivity, basic vegetative growth and optimum photoperiod. Euphytica 163(2): 167-175. DOI: https://doi.org/10.1007/s10681-007-9584-2

Vergara B.S. \& Chang T.T. (1985). The Flowering Response of the Rice Plant to Photoperiod-a Review of the Literature, fourth edition. The International Rice Research Institute, Los Baños, Laguna, The Philippines.

Wada E. (1942). On some characteristics of rice varieties of southern Asia. Kagaku (Science) 12(11): 441-444.

Wassmann R., Jagadish S.V.K., Heuer S., Ismail A., Redona E., Serraj R., Singh R.K., Howell G., Pathak H. \& Sumfleth K. (2009). Climate change affecting rice production: the physiological and agronomic basis for possible adaptation strategies. Advances in Agronomy 101: 59-122.

Wopereis M.C.S., Kropff M.J. \& Maligaya A.R. (2009). Reference 11: Effects of temperature on rice development. In: Curriculum for Participatory Learning and Action Research (PLAR) for Integrated Rice Management (IRM) in Inland Valleys of Sub-Saharan Africa: Technical Manual, pp. 45-48. Africa Rice Centre, Cotonou, Benin.

Yoshida S. (1973). Effects of temperature on growth of the rice plant (Oryza sativa L.) in a controlled environment. Soil Science and Plant Nutrition 19(4): 299-310.

Yoshida S. (1981). Fundamentals of Rice Crop Science, fourth edition. The International Rice Research Institute, Los Baños, Laguna, The Philippines. Available at http:// books.google.com/books? hl=en\&lr=\&id=323XxM076Ss $C \& o i=f n d \& p g=P P 2 \& o t s=k E T E a V S I 5-\& s i g=q F Z o I 1 V_{-}$ MpdjIA02NmNSrJpec8Q.

Yoshida S. (1983). Rice, Symposium on Potential Productivity of Field Crops under Different Environments (ed. W.H. Smith). The International Rice Research Institute, Los Baños, Laguna, The Philippines. 